\title{
TNF signaling drives myeloid-derived suppressor cell accumulation
}

\author{
Xueqiang Zhao,, ${ }^{1,2}$ Lijie Rong,, ${ }^{1,2}$ Xiaopu Zhao,, ${ }^{1,2}$ Xiao Li, ${ }^{1}$ Xiaoman Liu, ${ }^{1}$ Jingjing Deng, ${ }^{1,2}$ Hao Wu, \\ Xia Xu, ${ }^{1}$ Ulrike Erben, ${ }^{3}$ Peihua Wu, ${ }^{3}$ Uta Syrbe, ${ }^{3}$ Joachim Sieper, ${ }^{3}$ and Zhihai Qin'
} ${ }^{1}$ Key Laboratory of Protein and Peptide Pharmaceuticals, Chinese Academy of Sciences-University of Tokyo Joint Laboratory of Structural Virology and Immunology,
Institute of Biophysics, Chinese Academy of Sciences, Beijing, China. ${ }^{2}$ Graduate University of the Chinese Academy of Sciences, Beijing, China.

${ }^{3}$ Campus Benjamin Franklin, Charité, Berlin, Germany.

\begin{abstract}
TNF, an inflammatory cytokine that is enriched in the tumor microenvironment, promotes tumor growth and subverts innate immune responses to cancer cells. We previously reported that tumors implanted in TNF receptor-deficient $\left(\mathrm{Tnfr}^{-/-}\right)$mice are spontaneously rejected; however, the molecular mechanisms underlying this rejection are unclear. Here we report that TNF signaling drives the peripheral accumulation of myeloidderived suppressor cells (MDSCs). MDSCs expand extensively during inflammation and tumor progression in mice and humans and can enhance tumor growth by repressing $T$ cell-mediated antitumor responses. Peripheral accumulation of MDSCs was drastically impaired in Tn $\mathrm{fr}^{-/-}$mice. Signaling of TNFR-2, but not TNFR-1, promoted MDSC survival through upregulation of cellular FLICE-inhibitory protein (c-FLIP) and inhibition of caspase-8 activity. Loss of TNFRs impaired the induction of MDSCs from bone marrow cells, but this could be reversed by treatment with caspase inhibitors. These results demonstrate that TNFR-2 signaling promotes MDSC survival and accumulation and helps tumor cells evade the immune system.
\end{abstract}

\section{Introduction}

Inflammation has recently been recognized as one of the most important characteristics of tumor $(1,2)$. Among various inflammatory cells, myeloid-derived suppressor cells (MDSCs) have been demonstrated to be important negative immune regulators. In 1995, Schreiber's group reported that elimination of granulocytes in nude mice by the Gr1-specific mAb RB6-8C5 inhibits tumor growth (3). Further studies identified that it is $\mathrm{CD} 11 \mathrm{~b}^{+} \mathrm{Gr} 1^{+}$ myeloid cells (i.e., MDSCs) in mice that promote tumor progression $(4,5)$. MDSCs facilitate tumor growth mainly by suppressing antitumor responses of $\mathrm{T}$ cells and/or by promoting angiogenesis $(6,7)$. Reducing MDSC accumulation by direct depletion of these cells with RB6-8C5 retards tumor development and partly restores antitumor immunity in mice $(3,8)$. However, MDSCs are a heterogeneous population of cells consisting of myeloid progenitor cells and immature myeloid cells, making them almost impossible to be completely depleted. Therefore, knowing mechanisms governing MDSC accumulation may provide new strategies for targeting MDSCs in clinical trials against cancer.

TNF secreted by tumor or tumor stromal cells has been reported as an important regulator in the tumor microenvironment $(1,9)$. The role of TNF in tumor immunity is complex and remains controversial. Research using high doses of exogenous TNF or genemodified tumor cell lines secreting TNF demonstrate the antitumor activity of TNF (10-13). TNF was also implicated in the rejection of transplantable 3-methylcholanthrene-induced (MCAinduced) sarcomas and immune surveillance against spontaneous pancreatic tumors $(14,15)$. However, TNF also has tumor-promoting effects in various tumor models. TNF knockdown in epithelial ovarian cancer cells led to diminished tumor growth and reduced

Authorship note: Xueqiang Zhao, Lijie Rong, and Xiaopu Zhao contributed equally to this work.

Conflict of interest: The authors have declared that no conflict of interest exists. Citation for this article: J Clin Invest. 2012;122(11):4094-4104. doi:10.1172/JCI64115. vascular density (16). TNF knockout mice, as well as mice deficient in TNF receptor-1 (TNFR-1) and TNFR-2 (referred to herein as $\operatorname{Tnfr} 1^{-/-}$and $\mathrm{Tnfr} 2^{-/-}$mice, respectively), were more resistant to dimethylbenz-anthracene/tetradec-anoylphorbol-acetate-induced (DMBA/TPA-induced) skin carcinogenesis (17-19). In Tnfr1 ${ }^{-/}$ mice, reduced liver metastasis of colon 26 cells after intrasplenic administration has been observed (20). TNF is also involved in the induction and maturation of macrophages and dendritic cells, indicative of a crucial role in the differentiation of myeloid cells, including $\operatorname{MDSCs}(21,22)$.

By binding to TNFR-1 and TNFR-2, TNF activates distinct signaling pathways important for cell proliferation, cell survival, and immune responses (23-26). The default effect of TNF stimulation is to activate the NF- $\mathrm{BB}$ pathway and mediate inflammation. TNFR-1 mediates the cytotoxic effect through the death domain,

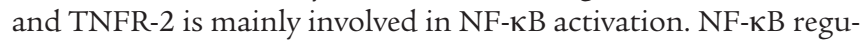
lates antiapoptotic products such as cellular FLICE-inhibitory protein (c-FLIP), blocks apoptosis initiated from the TRADD/FADD/ RIP-1/caspase- 8 complex, and maintains cell survival. However, whether the outcome of TNF regulation for cell apoptosis/survival depends on a balance between TNFR-1 and TNFR-2, on cell types, or on various inflammatory environments is currently not clear.

In the present study, we demonstrated that expression of TNFR-2 alone on MDSCs was necessary and sufficient for their survival, through upregulation of c-FLIP and downregulation of caspase- 8 activities. Our findings may hold important significance for the prevention and treatment of inflammation-related cancers.

\section{Results}

Transplanted tumors are often spontaneously rejected in Tnfr- ${ }^{-/}$mice. We previously reported that J558L tumors are often spontaneously rejected in mice deficient in both TNFRs (referred to herein as Tnfr $^{\prime-}$ mice), for unknown reasons (27). To exclude possible artifacts due to the contamination of microorganisms, J558L cells were passed 3 times in nude mice and then injected into mice. As 
A
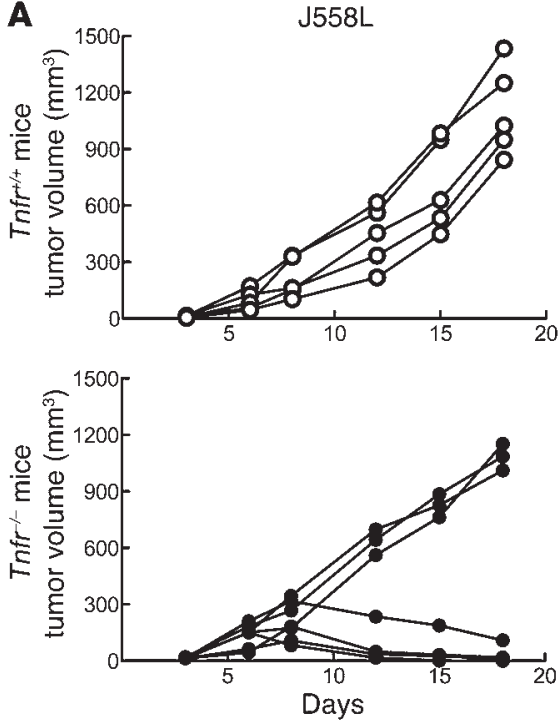

B
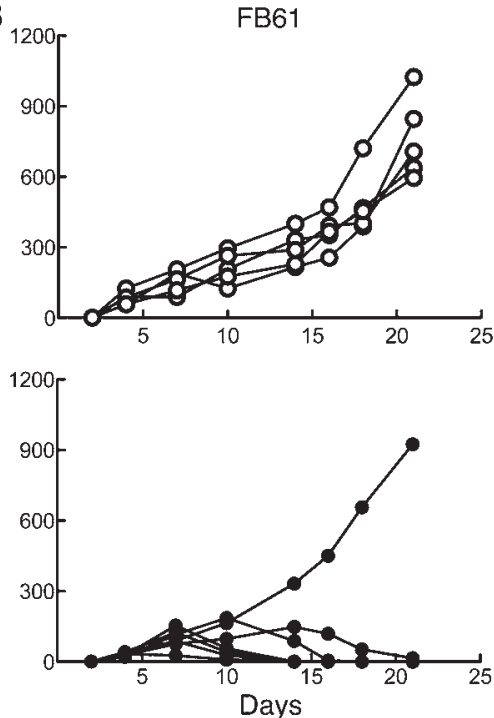

C
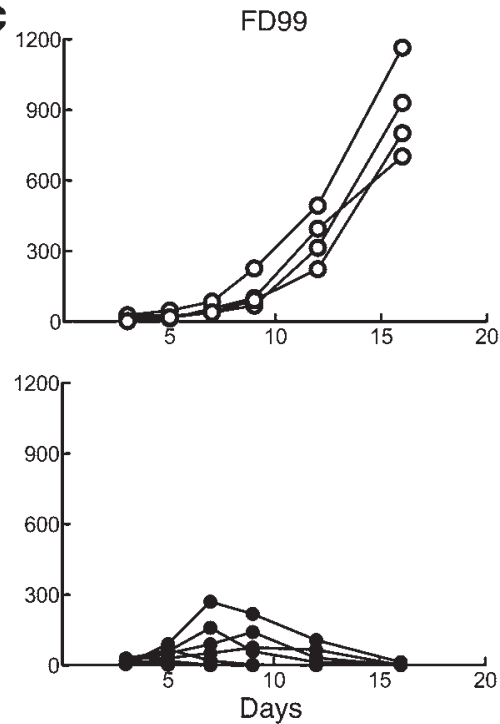

Figure 1

Transplanted tumors are spontaneously rejected in $\mathrm{Tnfr}^{-1}$ mice. $\mathrm{Tnfr}^{+/+}(n=4-5)$ and $\mathrm{Tnfr}^{-1-}(n=7)$ mice were subcutaneously injected with $($ A) $5 \times 10^{6} \mathrm{~J} 558 \mathrm{~L}$ cells, (B) $1 \times 10^{6} \mathrm{FB} 61$ cells, or (C) $1 \times 10^{6} \mathrm{FD} 99$ cells. Tumor volumes after tumor cell inoculation are shown; each line represents the growth curve of a tumor in a single mouse. Similar results were obtained from 2 other independent experiments.

shown in Figure 1A, beginning at 10 days after tumor cell inoculation, 4 of 7 tumors were spontaneously rejected in $\mathrm{Tnfr}^{-/-}$mice. To exclude the possibility that TNFRs on tumor cells act as antigens causing tumor rejection, we established several $\operatorname{Tn} \mathrm{Fr}^{-{ }^{--}}$and $\mathrm{Tnfr}^{-/}$tumor cell lines by MCA-induced carcinogenesis in Tnfr $1^{-/}$ and $\mathrm{Tnfr}^{-/-}$mice. These cells did not express the corresponding TNFRs, and the downstream signaling pathways were defective, as confirmed for FB61 cells by flow cytometry and Western blot (Supplemental Figure 1; supplemental material available online with this article; doi:10.1172/JCI64115DS1). Subsequently, the Tnfr1 $1^{-1}$ fibrosarcoma FB61 cells were subcutaneously injected into Tnfr ${ }^{-1}$ and $\mathrm{Tnfr}^{+/+}$mice (Figure 1B). Whereas 6 of 7 FB61 tumors were spontaneously rejected within around 3 weeks in $\mathrm{Tnfr}^{-/-}$mice, all 5 FB61 tumors in $\mathrm{Tnfr}^{+/+}$mice grew progressively during the same time period. Tnfr-/- FD99 tumor cells, originating from $\mathrm{Tnfr}^{-1}$ mice, were also tested. As shown in Figure 1C, all 7 FD99 tumors were completely rejected in $\mathrm{Tnfr}^{-1-}$ mice, but none of the tumors did so in the $\mathrm{Tnfr}^{+/+}$counterparts. These results demonstrated that the spontaneous tumor rejection in $\mathrm{Tnfr}^{-1}$ mice was caused not by immunogenicity of TNFR proteins on transplanted tumor cells, but by TNFR expression on host cells.

Tumor rejection is associated with impaired peripheral accumulation of MDSCs. To address the mechanisms responsible for the aberrant tumor growth in $\mathrm{Tnfr}^{-1}$ mice, we first analyzed immune cell populations in peripheral organs, such as tumors and spleens, at days 8-10, when tumors began to regress in Tnfr-/- mice. No clear difference was found for CD11 $\mathrm{c}^{+}$dendritic cells, B220 ${ }^{+} \mathrm{B}$ cells, or $\mathrm{CD}^{+}$cytotoxic or $\mathrm{CD}^{+} \mathrm{T}$ cells (including $\mathrm{CD}^{+} \mathrm{Foxp}^{+}{ }^{+}$regulatory $\mathrm{T}$ cells and $\mathrm{CD}^{+}{ }^{+}$Th17 cells) between FB61 tumor-bearing Tnfr ${ }^{-1}$ and $\mathrm{Tnfr}^{+/+}$mouse spleens (Supplemental Figure 2A). The density of blood vessels, as well as infiltrated $\mathrm{CD}^{+}$and $\mathrm{CD}^{+} \mathrm{T}$ cells in the tumor, were also similar between $\mathrm{Tnfr}^{-/-}$and $\mathrm{Tnfr}^{+/+}$mice (Supplemental Figure 2B). However, the percentages and absolute numbers of splenic $\mathrm{CD} 11 \mathrm{~b}^{+} \mathrm{Gr} 1^{+}$myeloid cells in tumor-bearing $\mathrm{Tnfr}^{-/}$mice were drastically reduced compared with those in their $\mathrm{Tnfr}^{+/+}$counterparts (Figure 2, A and B). Decreased proportions of CD11 $\mathrm{b}^{+} \mathrm{Gr} 1^{+}$ cells in tumor-bearing $\mathrm{Tnfr}^{-/}$mice were also observed in the peripheral blood and within the tumor (Figure 2, C and D). CD11b $\mathrm{br}^{+}$ cells from both $T n \mathrm{fr}^{+/+}$and $\mathrm{Tn} f \mathrm{r}^{-/-}$tumor-bearing mice, but not from control mice, inhibited the proliferation of $\mathrm{CD}^{+} \mathrm{T}$ cells (Supplemental Figure 3A). Compared with the cells from control animals, they exhibited increased arginase and iNOS activities and produced higher levels of immune-suppressive cytokine IL-10 (Supplemental Figure 3, B-D). Therefore, the $\mathrm{CD} 11 \mathrm{~b}^{+} \mathrm{Gr} 1^{+}$cells from the tumorbearing mice were also named as $\operatorname{MDSCs}(13,28,29)$.

To investigate local distributions of the $\mathrm{CD} 11 \mathrm{~b}^{+} \mathrm{Gr} 1^{+} \mathrm{MDSCs}$ in the absence of TNFR, immunofluorescence staining was performed in tumors and spleens. Although the number of CD $11 \mathrm{~b}^{+}$ and $\mathrm{Gr}^{+}$cells was reduced within $\mathrm{Tnfr}^{-/}$tumor sites, the distribution of cells did not differ in $\mathrm{Tnfr}^{+/+}$and $\mathrm{Tnfr}^{-/-}$mice (Figure 2E). In spleens, germinal center structures were disturbed in $\mathrm{Tnfr}^{-1-}$ mice, but again, the distribution patterns of $\mathrm{CD} 11 \mathrm{~b}^{+}$and $\mathrm{Gr} 1^{+}$cells were similar to those of $\mathrm{Tnfr}^{+/+}$controls. The activation status of $\mathrm{Tnfr}^{-/}$ compared with $\mathrm{Tnfr}^{+/+}$MDSCs showed no obvious changes in surface expression of the costimulatory molecules CD80, CD86, and B7-H1; the cytokine receptor IL-4R; the antigenic peptide-presenting molecules $\mathrm{H} 2-\mathrm{K}^{\mathrm{d}}$ and $\mathrm{I}-\mathrm{A}^{\mathrm{d}}$; and the apoptosis-related molecules CD95 and CD95L (Figure 2F). These results indicated that TNF signaling contributed to enhanced MDSC accumulation in spleen and tumor, but did not influence the cells' immunosuppressive function and distribution in organs.

Adoptive transfer of $\mathrm{Tnfr}^{+/+}$MDSCs restores tumor growth in $\mathrm{Tnfr}^{-1-}$ mice in a dose-dependent manner. To confirm that the lack of TNFRs on MDSCs was attributable to impaired $\mathrm{Tnfr}^{-/-}$mouse tumor growth, we purified $T n f r^{+/+}$and $T n f r^{-/}$spleen MDSCs and adoptively transferred them to $\mathrm{Tnfr}^{-/-}$and $\mathrm{Tnfr}^{+/+}$mice. Subsequently, Tnfr $1^{-1-}$ FB61 fibrosarcoma cells were used to challenge the MDSC recipient mice. In $\operatorname{Tnfr}^{-/-}$recipients of $\operatorname{Tnfr}^{-/-}$MDSCs (referred to 
A
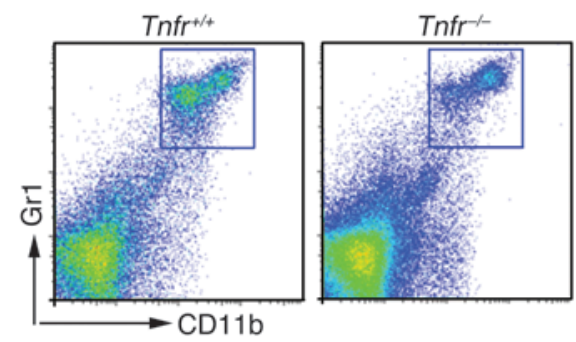

Spleen
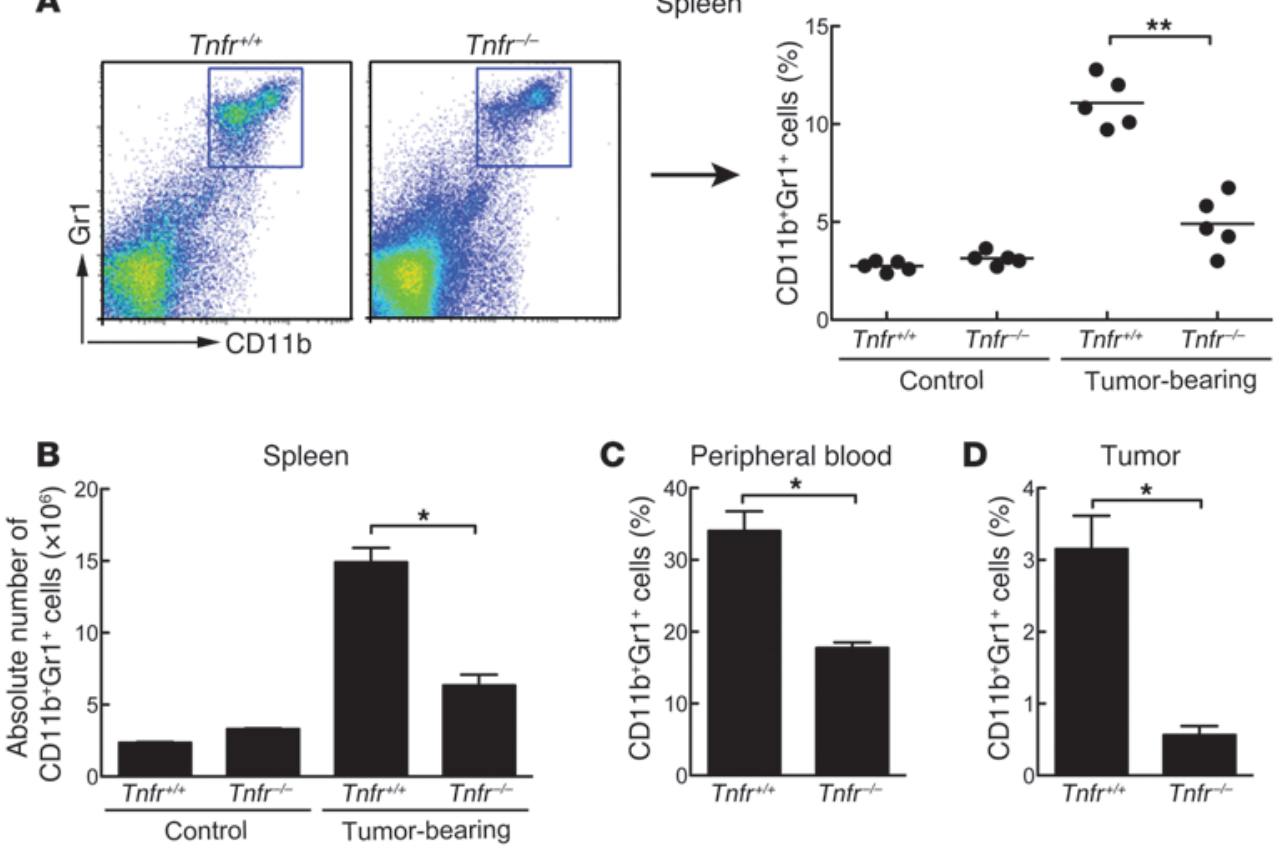

C

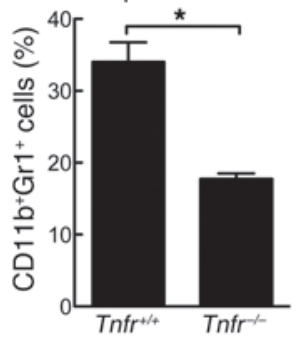

D

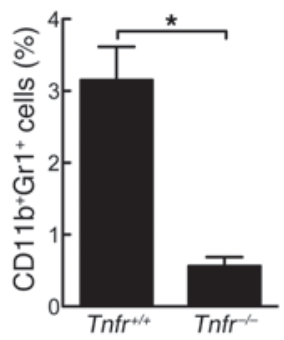

E

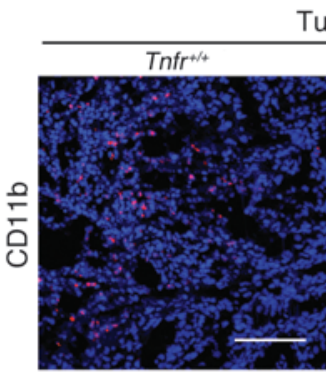

Tumor
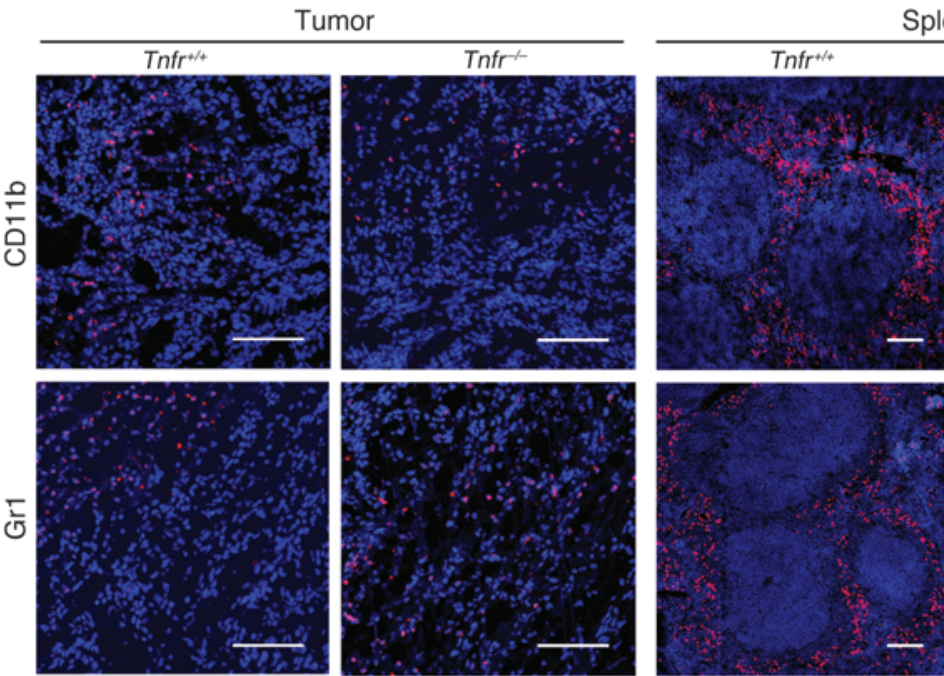

Spleen
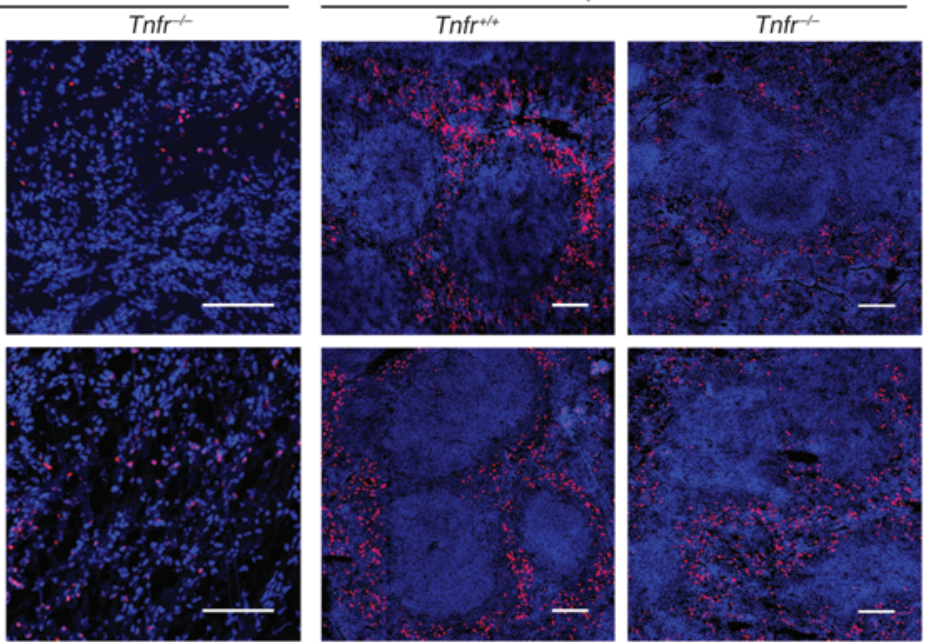

$\mathbf{F}$
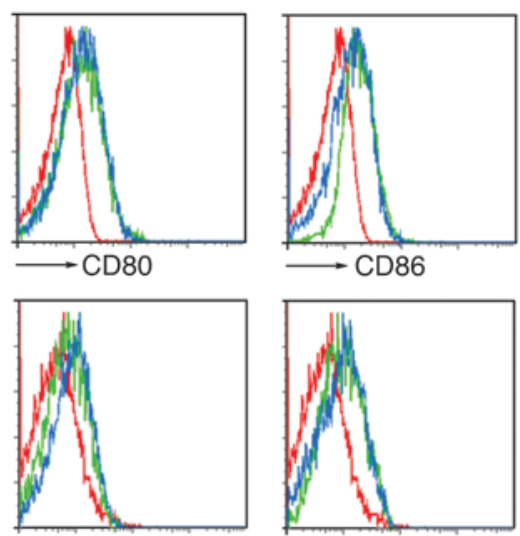

$-\mathrm{H} 2-\mathrm{k}^{\mathrm{d}}$
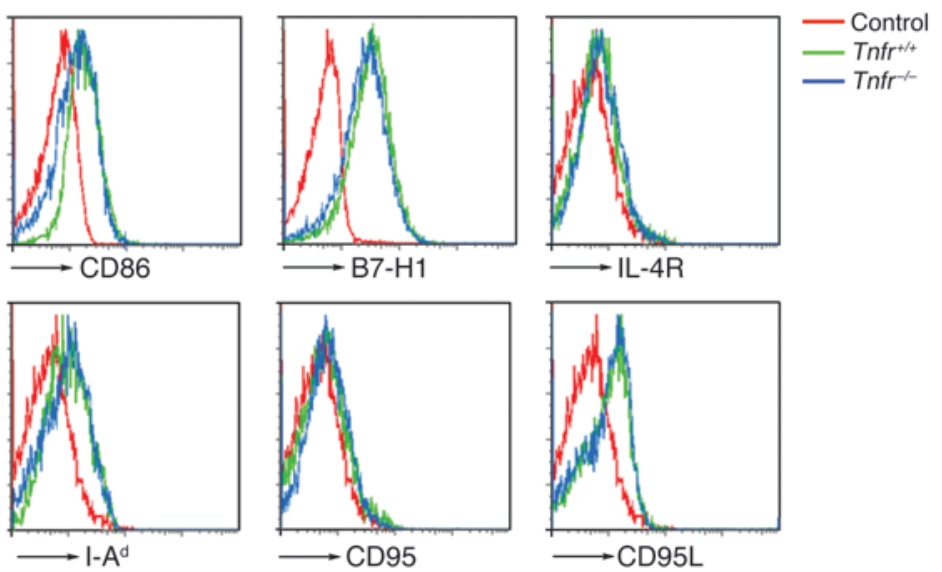

Figure 2

Peripheral accumulation of $\mathrm{CD} 11 \mathrm{~b}+\mathrm{Gr} 1^{+}$cells is impaired in Tnfr-l- mice. (A) Tnfr't+ and Tnfr-1- mice were subcutaneously injected with $1 \times 10^{6} \mathrm{FB} 61$ cells or PBS as control. 8-10 days after tumor cell inoculation, single splenocytes were stained for CD11b and Gr1 and assessed by flow cytometry. Left: Gated CD11b+Gr1+ cells. Right: Percent CD11b+Gr1+ cells in tumor-bearing $\mathrm{Tnfr}^{+/+}$and $\mathrm{Tnfr}^{-1}$ mice and corresponding controls. Bars denote means. ${ }^{* *} P<0.01$. (B) Absolute number of $C D 11 b+G r 1+$ cells in spleens of tumor-bearing mice and corresponding controls. Data are mean \pm SEM. ${ }^{*} P<0.05$. (C and D) Percent CD11b+Gr1+ cells relative to total cells for (C) peripheral blood and (D) tumor tissues. $n=5$ per group. Data are mean \pm SEM. ${ }^{*} P<0.05$. (E) $\mathrm{CD}_{11 \mathrm{~b}^{+}}$and $\mathrm{Gr} 1^{+}$cells in tumor and spleen sections of $\mathrm{Tnfr}^{+/+}$ and $\mathrm{Tnfr}^{-1}$ mice were visualized by immunofluorescence staining. Nuclei were counterstained with DAPI. Images are representative of at least 3 mice per group. Original magnification, $\times 200$ (tumor); ×100 (spleen). Scale bars: $300 \mu \mathrm{m}$. (F) Spleen cells as above were stained for flow cytometry analysis. Unstained Tnfr+/+ splenocytes were used as a control. 


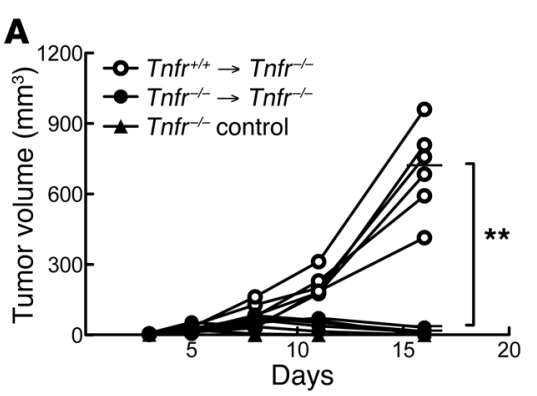

B

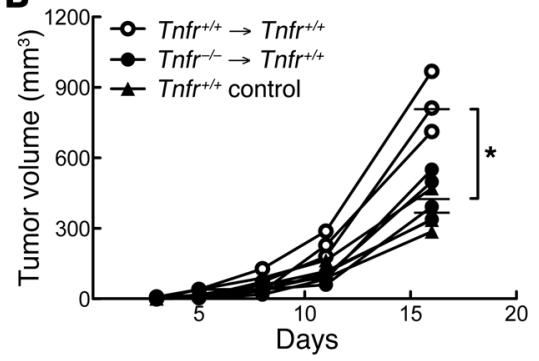

$c$

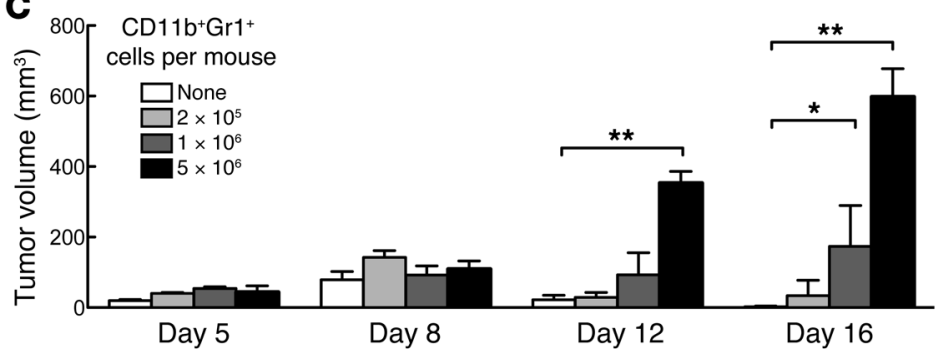

\section{Figure 3}

Adoptive transfer of $\mathrm{Tnfr}^{+/+} \mathrm{CD} 11 \mathrm{~b}+\mathrm{Gr} 1^{+}$cells restores tumor growth in $\mathrm{Tnfr}^{-1}$ mice in a dosedependent manner. (A and B) Purified $\mathrm{Tnfr}^{++}$or Tnfr-l- CD11 $^{-}+\mathrm{Gr} 1+$ cells $\left(5 \times 10^{6}\right)$ were intravenously injected into $\mathrm{Tnfr}^{-1-}(\mathbf{A} ; n=5-6)$ or $\mathrm{Tnfr}^{+/+}$ (B; $n=3-4)$ mice. Untreated mice served as controls. 12 hours later, mice were subcutaneously injected with $1 \times 10^{6}$ FB61 cells. Shown are tumor volumes after tumor cell inoculation. Lines represent growth curves of a tumor in a single mouse; bars denote mean tumor size of each group at day 16. ${ }^{\star} P<0.05$; ${ }^{* *} P<0.01$. (C) $\mathrm{Tnfr}^{-1-}$ mice were adoptively transferred without or with $2 \times 10^{5}, 1 \times 10^{6}$, or $5 \times 10^{6}$ purified $\mathrm{Tnfr}^{+/+}$ CD11b+Gr1+ cells by intravenous injection; 12 hours later, they were injected subcutaneously with $1 \times 10^{6}$ FB6 1 cells. Tumor volumes are presented as mean \pm SEM. $n=5$ or 7 per group. ${ }^{\star} P<0.05 ;{ }^{* \star} P<0.01$. herein as $\mathrm{Tnfr}^{-1-} \rightarrow \mathrm{Tnfr}^{-1-}$ mice), all tumors grew for a few days before the expected regression (Figure $3 \mathrm{~A}$ ). These mice were protected against subsequent FB61 challenges (data not shown), indicative of the establishment of effective antitumor immunity. However, in $\mathrm{Tnfr}^{+/+} \rightarrow \mathrm{Tnfr}^{-/-}$mice, all tumors grew progressively and reached a mean volume of $700 \pm 100 \mathrm{~mm}^{3}$ within 16 days, which highlighted that TNFR expression on MDSCs was crucial for tumor development. The recovery of tumor growth could be attributed to the attenuated antitumor $T$ cell response, since IFN- $\gamma$ production and tumor-specific $\mathrm{CD}^{+} \mathrm{T}$ cell proliferation were significantly suppressed in these mice (Supplemental Figure 4). When $\mathrm{Tnfr}^{-/-} \rightarrow \mathrm{Tnfr}^{+/+}$mice were challenged with tumors, all tumors grew, but did so more slowly than those in $\mathrm{Tnfr}^{+/+} \rightarrow \mathrm{Tnfr}^{+/+}$ mice (Figure 3B). As Tnfr ${ }^{-/}$MDSCs - like Tnfr ${ }^{+/+}$MDSCs - were immunosuppressive (Supplemental Figure 3), this retarded tumor growth may be due to the quantity, but not the quality, of transferred MDSCs. To confirm this hypothesis, Tnfr ${ }^{-1-}$ mice were adoptively transferred with decreasing dose of $\operatorname{Tnfr} r^{+/} \mathrm{CD}_{11} \mathrm{~b}^{+} \mathrm{Gr} 1^{+}$cells and challenged with FB61 tumor cells. As shown in Figure 3C, a dose of more than $1 \times 10^{6} \mathrm{Tnfr}^{+/+}$MDSCs per mouse was necessary to make a significant tumor-promoting effect within 16 days of tumor cell injection.

To further study the fate of MDSCs after adoptive transfer, $\mathrm{CD}_{11} \mathrm{~b}^{+} \mathrm{Gr} 1^{+}$cells were isolated from eGFP-transgenic mice bearing MCA205 (also an MCA-induced fibrosarcoma cell line in C57BL/6 mice) tumors. Similar to the experiments above, cells were adoptively transferred, and MCA205 tumor cells were inoculated into syngeneic C57BL/6 recipient mice. Although in peripheral blood, $\mathrm{eGFP}^{+}$cells were hardly detectable at day 3 after tumor cell inoculation (Supplemental Figure 5, A and B), a group of these $\mathrm{eGFP}^{+}$cells could be traced in spleen until day 7 and in tumors until day 10 , which indicates that adoptively transferred MDSCs did participate in tumor development. Furthermore, eGFP ${ }^{+}$ MDSCs were detected in the vicinity of $\mathrm{T}$ cells in the outer rim of tumors (Supplemental Figure 5C), indicative of effective suppression of local T cell immunity by donor MDSCs. Together, these results strongly suggest that impaired peripheral accumulation of MDSCs accounts for impaired tumor growth in $\mathrm{Tnfr}^{-1-}$ mice.
TNFR expression on MDSCs was necessary and sufficient for the MDSC-mediated tumor-promoting effect.

Enhanced apoptosis is responsible for reduced MDSC numbers in Tnfr-1mice. It is well known that TNF elicits different cellular responses, such as cell proliferation or apoptosis (30). Because the reduced numbers of MDSCs in Tnfr-/- mice could be attributable to decreased proliferation or increased apoptosis, we used BrdU to determine the proliferation of MDSCs. BrdU incorporation in bone marrow MDSCs showed no differences between FB61 tumor-bearing $\mathrm{Tnfr}^{-/-}$and $\mathrm{Tnfr}^{+/+}$mice (Figure 4A), which indicates that MDSC proliferation was not influenced. Similar results were obtained in spleen MDSCs (data not shown). However, in the same time period, when $\mathrm{CD} 11 \mathrm{~b}^{+} \mathrm{Gr} 1^{+}$cells were stained with anti-annexin $\mathrm{V}$ antibody to detect apoptosis (Figure 4B), a drastic increase of annexin $\mathrm{V}^{+}$

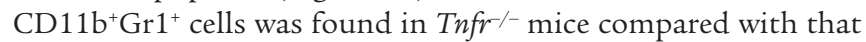
in controls ( $24 \% \pm 5 \%$ vs. $4 \% \pm 3 \%$; Figure $4 \mathrm{C})$. These results suggest that the impaired accumulation of MDSCs in $\mathrm{Tnfr}^{-1}$ mice during tumor growth was not due to the decreased proliferation, but the increased apoptosis of these cells in the absence of TNFR.

To further investigate why TNF signaling is crucial for protecting MDSCs from apoptosis, activities of apoptosis-related caspases were determined in splenic MDSCs. More than a 3-fold increase of caspase-8 activity was found in purified Tnfr-/- versus $\mathrm{Tnfr}^{+/+}$ $\mathrm{CD}_{11} \mathrm{~b}^{+} \mathrm{Gr} 1^{+}$cells $(1.28 \pm 0.18$ vs. $0.32 \pm 0.06$; Figure 4D), but no increase of caspase- 3 or caspase- 9 activity was observed (data not shown). Western blot analysis confirmed this observation, since the levels of cleaved caspase-8 also increased in purified $\mathrm{Tnfr}^{-1-}$ relative to $\mathrm{Tnfr}^{+/+}$MDSCs (Figure 4E).

To confirm that increased MDSC apoptosis in the absence of TNFR signaling is caused by enhanced caspase- 8 activity, MDSCs were induced from bone marrow cells of $\mathrm{Tnfr}^{-/-}$and $\mathrm{Tnfr}^{+/+}$mice. Within 5 days of in vitro culture, significantly fewer $\mathrm{CD} 11 \mathrm{~b}^{+} \mathrm{Gr} 1^{+}$ cells were induced in the absence of the TNFRs $(25 \% \pm 2 \%$ vs. $42 \% \pm 3 \% ; P<0.01$; Figure $4 \mathrm{~F})$. Addition of either the pan-caspase inhibitor Z-Val-Ala-Asp (OMe)- $\mathrm{CH}_{2} \mathrm{~F}(\mathrm{z}$-VAD; $41 \% \pm 2 \%)$ or the caspase-8-specific inhibitor Z-Ile-Glu(OMe)-Thr-Asp $(\mathrm{OMe})-\mathrm{CH}_{2} \mathrm{~F}$ $(\mathrm{z}-\mathrm{IETD} ; 44 \% \pm 2 \%)$ restored accumulation of $\mathrm{CD} 11 \mathrm{~b}^{+} \mathrm{Gr} 1^{+}$cells, to the level of $\mathrm{Tnfr}^{+/+}$cells (Figure 4F). These results demonstrated 
A

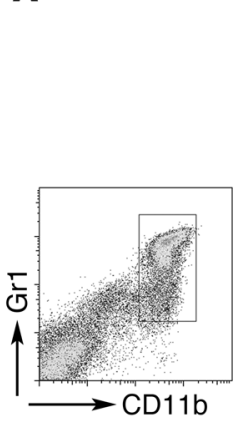

Day 3

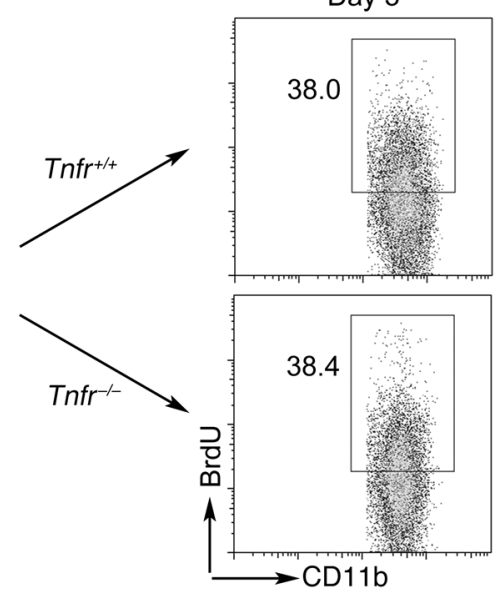

Day 5
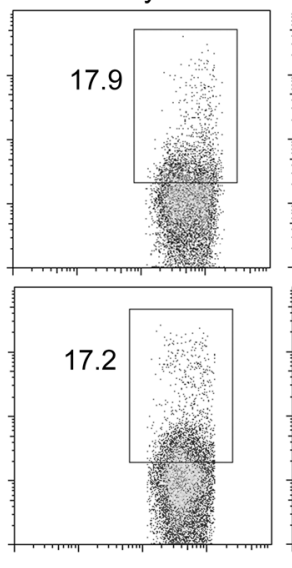

$\mathbf{E}$
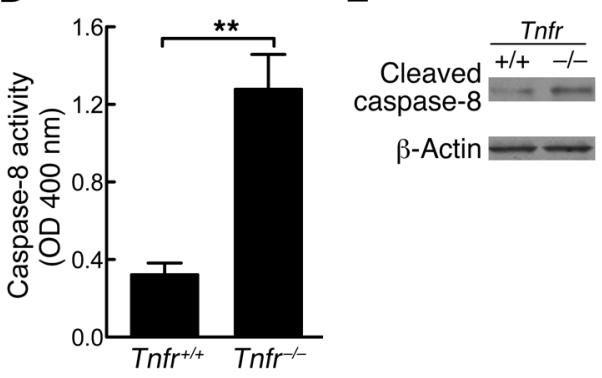

Day 8
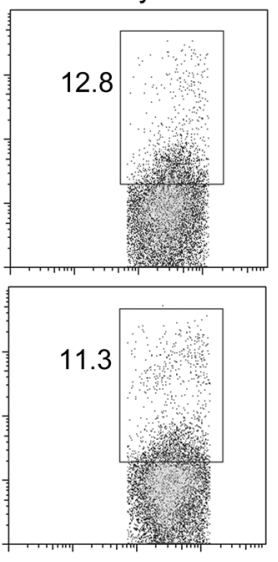

B

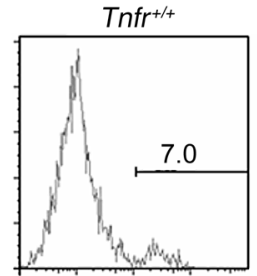

$\mathrm{Tnfr}^{-1}$

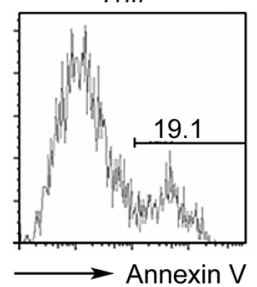

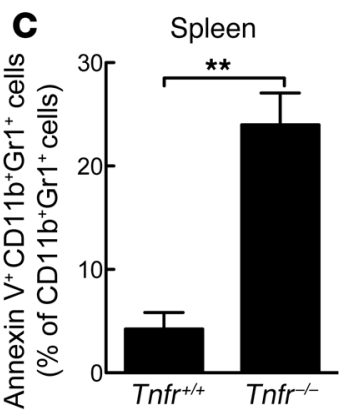

F

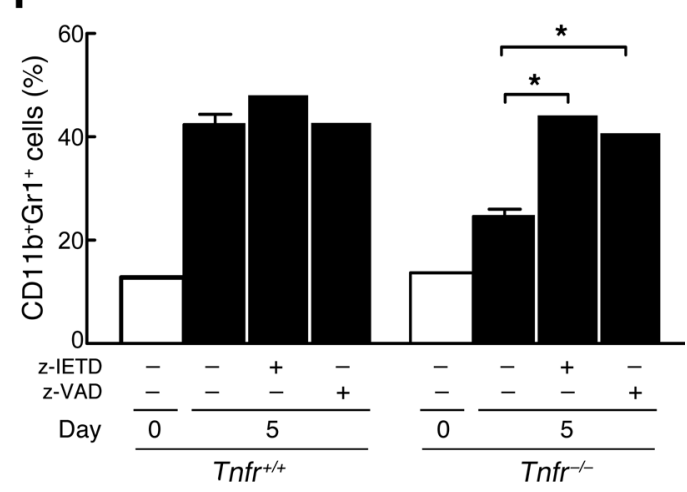

Figure 4

Enhanced caspase-8 activity is responsible for the impaired accumulation of CD11 b $\mathrm{br}^{+1^{+}}$cells in $\mathrm{Tnfr}^{-1-}$ mice. (A) $\mathrm{Tnfr}^{+/+}$and Tnfr-1- mice were

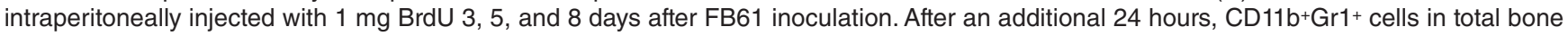
marrow cells were gated (left), and BrdU incorporation was determined (right). Numbers indicate percent BrdU+ cells in gated cells. $n=5$ per group. (B) Spleen cells were prepared 8-10 days after FB61 cell inoculation and stained for CD11b, Gr1, and annexin V. Numbers denote percent annexin $\mathrm{V}+$ cells in gated $C D 11 b+G r 1+$ cells. (C) Proportion of annexin $V+C D 11 b+G r 1+$ cells, expressed as percent of total CD11b+Gr1+ cells

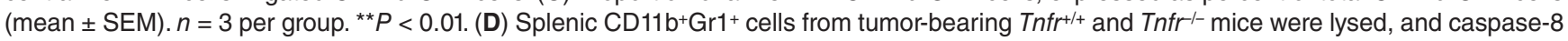
activities were determined by colorimetric activity assay (mean \pm SEM). $n=3-5$ per group. ${ }^{* *} P<0.01$. (E) Total cell lysates were subjected to cleaved caspase-8-specific Western blot. $\beta$-actin served as internal control. (F) MDSCs were in vitro induced from $\mathrm{Tnfr}^{+/+}$and $\mathrm{Tnfr}^{-1-}$ bone marrow cells. 6 hours later, z-VAD, z-IETD, or DMSO (as control) was added to the medium. Data (mean \pm SEM) denote percent CD11b+Gr1+ cells in total living cells in the culture. ${ }^{*} P<0.05$.

that lack of TNFR signaling led to enhanced caspase-8 activation and therefore accelerated MDSC apoptosis. Thus, TNFR signaling is necessary for maintaining antiapoptotic activities in MDSCs.

$N F-\kappa B$-mediated c-FLIP expression is downregulated in Tnfr ${ }^{-1-}$ MDSCs. c-FLIP is a natural inhibitor of caspase-8. To investigate whether c-FLIP is involved in influencing MDSC apoptosis, its expression was determined at the transcriptional level in purified splenic $\mathrm{CD}_{11 \mathrm{~b}} \mathrm{Gr}^{+}$cells. Corresponding to the enzymatic activities (Figure 4, D and E), significantly decreased c-FLIP - rather than Bcl- $\mathrm{x}_{\mathrm{L}}$, another antiapoptotic protein that serves as a caspase- 9 inhibitor - was found in Tnfr ${ }^{-1}$ MDSCs (Figure 5A). Similarly, Western blot confirmed decreased intracellular c-FLIP and increased cleaved caspase- 8 in Tnfr ${ }^{-/}$MDSCs, whereas Bcl- $\mathrm{x}_{\mathrm{L}}$ level did not markedly change (Figure 5B).

c-FLIP expression can be regulated by NF- $\mathrm{KB}$ pathway activa-

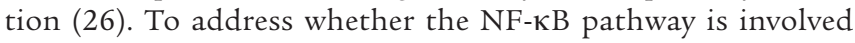

here, recombinant mouse TNF was added to cultures of $\mathrm{Tnfr}^{+/+}$

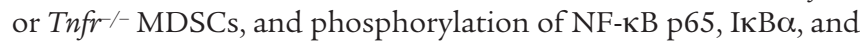
IKK $\alpha / \beta$ over time was studied. In $\mathrm{Tnfr}^{+/+}$MDSCs, the protein level of $\mathrm{p}-\mathrm{IKK} \alpha / \beta$ steadily increased over 30 minutes, whereas $\mathrm{p}-\mathrm{NF}-\kappa \mathrm{B}$ $\mathrm{p} 65$ and $\mathrm{p}-\mathrm{I} \kappa \mathrm{B} \alpha$ peaked at 15 minutes (Figure 5C). This was accompanied by an increase of c-FLIP and inhibited cleavage of caspase- 8 within 48 hours. However, in MDSCs from $\mathrm{Tnfr}^{-/}$mice, steady low

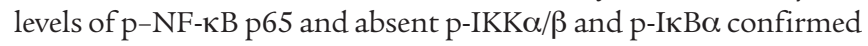
the lack of functional receptors of TNF. This was accompanied by reduced c-FLIP between 12 and 36 hours and a simultaneous increase in cleaved caspase-8. These data indicate that TNF induces c-FLIP upregulation through the NF-кB pathway in MDSCs.

TNFR-2 alone is crucial for the accumulation of MDSCs. TNF binds to 2 receptors, the ubiquitously expressed TNFR-1 and the hematopoietic cell-restricted TNFR-2. Flow cytometry analysis showed that both TNFR-1 and TNFR-2 were expressed on MDSCs (Sup- 

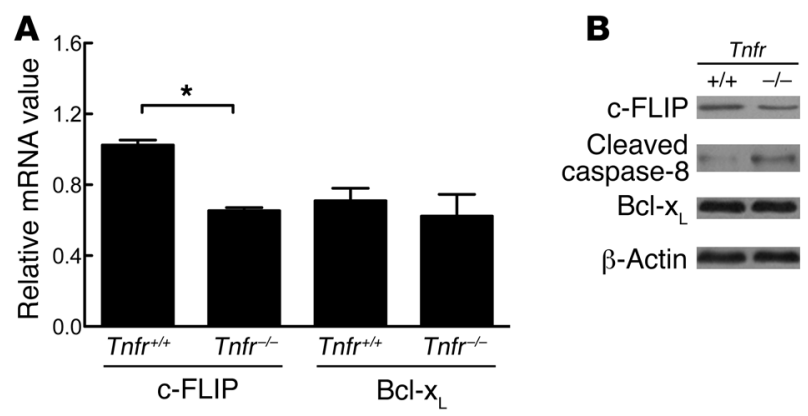

C

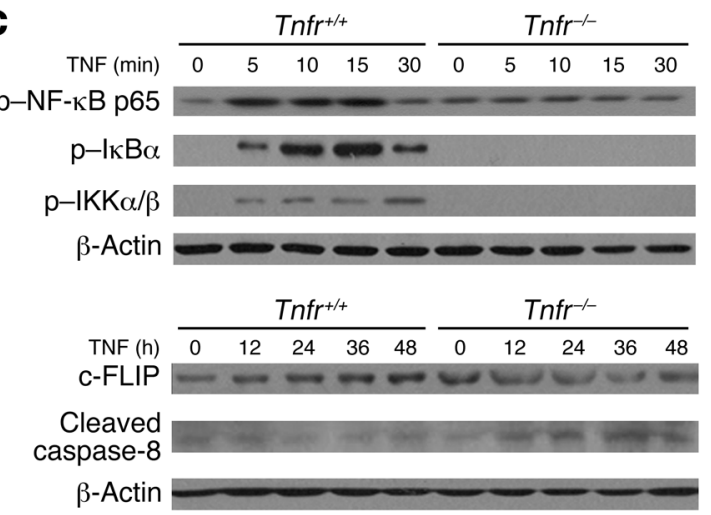

plemental Figure 6). We next analyzed whether both receptors are equally important for peripheral accumulation of MDSCs during tumor development. FB61 fibrosarcoma cells were subcutaneously injected into $\mathrm{Tnfr}^{+/+}, \mathrm{Tnfr} \mathrm{1}^{-/-}, \mathrm{Tnfr} 2^{-/-}$, and $\mathrm{Tnfr}^{-/-}$mice, and tumor growth as well as peripheral accumulation of MDSCs in spleen were observed. Again, tumors grew progressively in $\mathrm{Tnfr}^{+/+}$ mice (Figure 6A). In contrast, in Tnfr ${ }^{--}$and Tnfr2 $2^{-1-}$ mice, but not Tnfr $1^{-1-}$ mice, tumor growth was significantly retarded from day 14 after tumor cell inoculation. Furthermore, 5 of 10 FB61 tumors were spontaneously rejected in $\mathrm{Tnfr} \mathrm{2}^{-/-}$mice, similar to $\mathrm{Tnfr} \mathrm{r}^{--}$mice (data not shown). In keeping with the retarded tumor growth,

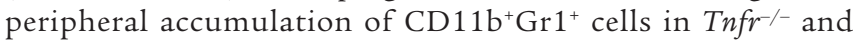
Tnfr2 $2^{-/}$spleens was significantly impaired, by nearly half (Figure $6 \mathrm{~B})$, but the reduced $\mathrm{CD} 11 \mathrm{~b}^{+}$or $\mathrm{Gr}^{+}$cells still located around the germinal centers (Figure 6C).

To further confirm the importance of TNFR-2 for MDSC accumulation, $\mathrm{CD}_{1} \mathrm{~b}^{+} \mathrm{Gr} 1^{+}$cells from tumor-bearing Tnfr $1^{-/}$and Tnfr2 $2^{-/}$mice were stimulated in vitro with TNF. The molecules involved in the activation of NF- $\mathrm{KB}$ and apoptosis were determined. As shown in Figure 6D, in Tnfr1 $1^{-/-}$MDSCs, levels of TNFRassociated factor 2 (TRAF2) and $\mathrm{p}-\mathrm{NF}-\mathrm{\kappa B}$ p 65 increased and peaked at 10 minutes. Levels of $\mathrm{p}$-IKB $\alpha$ and $\mathrm{p}-\mathrm{IKK} \alpha / \beta$ in $\operatorname{Tnfr} 1^{-/-}$ MDSCs exhibited increases similar to those in $\mathrm{Tnfr}^{+/+}$cells (Figure 5C), although the pattern was altered slightly. However, in Tnfr $2^{-/-}$ MDSCs, there was no substantial upregulation of TRAF2 or $\mathrm{p}-\mathrm{NF}-\kappa \mathrm{B}$ p 65 , and hardly any $\mathrm{p}-\mathrm{I} \kappa \mathrm{B} \alpha$ or $\mathrm{p}-\mathrm{IKK} \alpha / \beta$ was detected. This indicates that TNFR-2 is sufficient for activation of the $\mathrm{NF}-\kappa \mathrm{B}$ signaling pathway in MDSCs.

Correspondingly, an increase of c-FLIP and a decrease of the cleaved form of caspase- 8 in $\operatorname{Tnfr} 1^{-/-} \mathrm{CD} 11 \mathrm{~b}^{+} \mathrm{Gr} 1^{+}$cells was observed during the first 36-48 hours of TNF stimulation. On the contrary, lack of TNFR-2 signaling showed a proapoptotic pattern, with reduced c-FLIP and increased caspase- 8 over time.

\section{Figure 5}

NF-кB-mediated C-FLIP expression is downregulated in $\mathrm{Tnfr}^{-1-}$ MDSCs. (A) CD11b+Gr1+ cells were freshly isolated from $\mathrm{Tnfr}^{+/+}$and

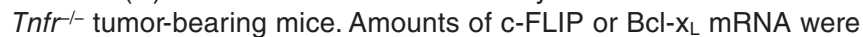
determined by real-time RT-PCR and are shown relative to $\beta$-actin mRNA (mean \pm SEM). ${ }^{*} P<0.05$. (B) Total cell lysates were extracted from purified $\mathrm{Tnfr}^{+/+}$and $\mathrm{Tnfr}^{-1}$ MDSCs. Levels of C-FLIP, cleaved caspase-8, and $\mathrm{Bcl}-\mathrm{x}_{\mathrm{L}}$ were determined by Western blot. $\beta$-actin served as internal control. (C) Purified MDSCs were stimulated with $20 \mathrm{ng} / \mathrm{ml} \mathrm{TNF}$ for the indicated times. Levels of $\mathrm{p}-\mathrm{NF}-\kappa \mathrm{B} \mathrm{p} 65, \mathrm{p}-\mathrm{I}_{\mathrm{KB}} \alpha$, and $\mathrm{p}-\mathrm{IKK} \alpha / \beta$, as well as c-FLIP and cleaved caspase-8, were determined from total cell lysates by Western blot. $\beta$-actin served as internal control. Representative images are shown for 3 independent experiments.

Interestingly, TNFR-2 deficiency in MDSCs did not affect their $\mathrm{T}$ cell-suppressive function, and there was also no significant difference in arginase or iNOS activity between Tnfr $2^{-1-}$ MDSCs and their $\mathrm{Tnfr}^{+/+}$counterparts (Supplemental Figure 7). These results demonstrated that TNFR-2 signaling was necessary and also sufficient for the protection of MDSCs from apoptosis.

Neutralization of endogenous TNF impairs transplanted tumor growth and accumulation of MDSCs. Both TNF and lymphotoxin can bind to TNFR-1 and TNFR-2 in vivo. To investigate whether endogenous TNF is necessary for MDSC accumulation during tumor growth, mice were treated with the TNF-neutralizing $\mathrm{mAb}$ V1q or its isotype control, then subcutaneously injected with FB61 cells. Neutralization of endogenous TNF led to a significant delay of tumor growth (Figure 7A). Whereas all FB61 tumors grew out in the control mice, 4 of 6 FB61 tumors were spontaneously rejected in the V1q-treated group. Similar antitumor effects were observed in J558L plasmacytoma and TSA mammary adenocarcinoma after V1q treatment (data not shown). Accordingly, splenic MDSC accumulation was also reduced after neutralization of endogenous TNF, especially at a later time point (Figure 7B). For example, at day 15 after tumor cell injection, whereas $\mathrm{CD}_{11 \mathrm{~b}^{+} \mathrm{Gr} 1^{+}}$ cells accounted for $32 \% \pm 6 \%$ of total spleen leukocytes in control mice, they accounted only for $8 \% \pm 5 \%$ in the TNF-neutralized mice (Figure 7B). Similarly, intratumoral accumulation of MDSCs also decreased after TNF neutralization $(1.25 \% \pm 0.4 \%$ vs. $3.9 \% \pm 0.7 \%$ in isotype controls at days 8-10; Figure 7C).

The in vitro MDSC induction was also performed to confirm the role of TNF in MDSC accumulation. After a 5-day culture, $\mathrm{CD}_{11} \mathrm{~b}^{+} \mathrm{Gr} 1^{+}$cell frequency increased from $13 \% \pm 2 \%$ to $42 \% \pm 6 \%$ (Figure 7D). Addition of V1q abrogated this increase to $22 \% \pm 12 \%$. However, addition of $z$-IETD drastically reverted the effect of TNF neutralization on MDSC induction (38\% $\pm 12 \%)$. Taken together, these observations indicate that both host-derived TNF and expression of TNFR-2 on MDSCs are required for MDSC accumulation during transplanted tumor growth.

\section{Discussion}

In this study, we demonstrated that impaired accumulation of MDSCs in $\mathrm{Tnfr}^{-/-}$mice clearly contributed to retarded tumor growth. TNF maintained peripheral accumulation of MDSCs through TNFR-2 by inducing the expression of c-FLIP, which inhibited activation of apoptotic caspase-8. Our study revealed one mechanism by which TNF maintains peripheral MDSC accumulation and therefore promotes tumor growth, which indicates that caspase inhibitors or anti-TNF mAb may improve the clinical treatment of cancer and inflammatory diseases. 


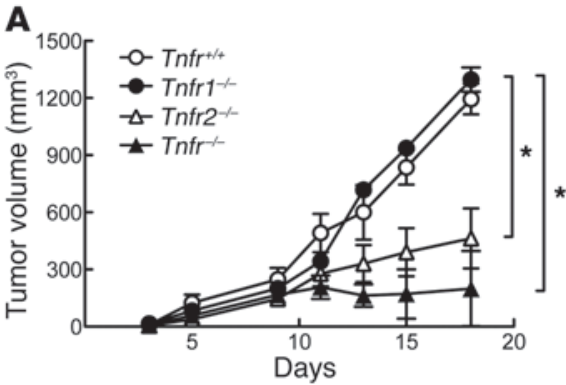

C
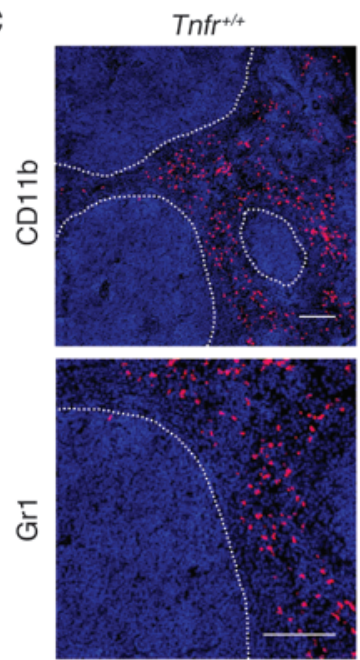

D

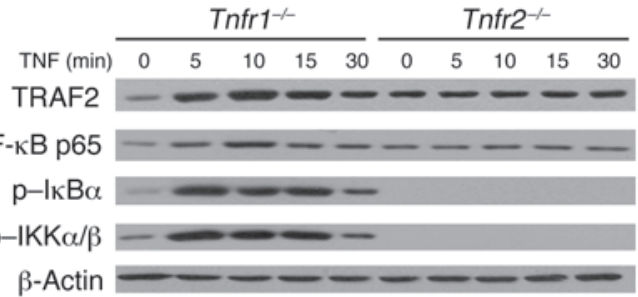

B
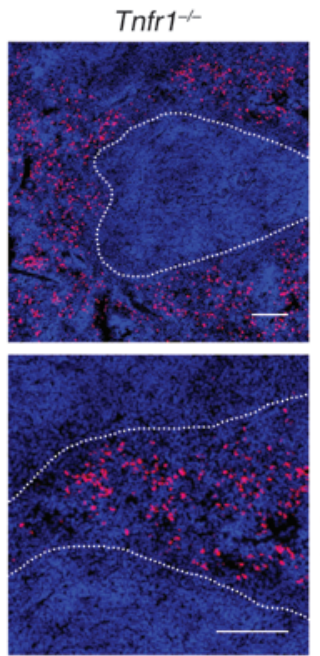
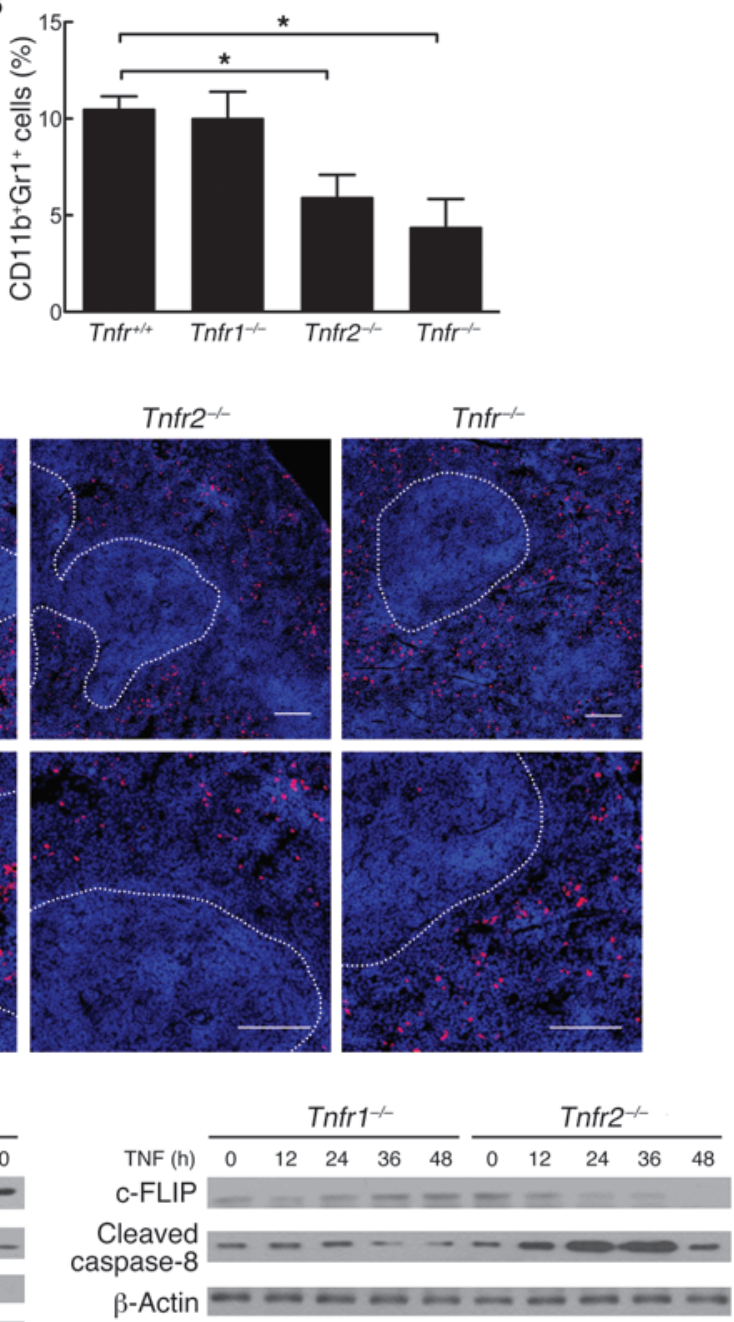

$\beta$-Actin

\section{Figure 6}

TNFR-2 signaling maintains survival of CD11b ${ }^{+} \mathrm{Gr} 1^{+}$cells. (A) $\mathrm{Tnfr}^{+/+}, \mathrm{Tnfr}^{-1-}$, Tnfr2 ${ }^{-/-}$, and $\mathrm{Tnfr}^{-1}$ mice were subcutaneously injected with $1 \times 10^{6}$ FB61 cells. Tumor volumes were measured after tumor cell inoculation (mean \pm SEM). $n=5-7$ per group. ${ }^{*} P<0.05$. (B) Spleen cells were prepared 8-10 days after tumor cell inoculation, stained for CD11b and Gr1, and analyzed by flow cytometry. Data (mean \pm SEM) represent percent $\mathrm{CD} 11 \mathrm{~b}+\mathrm{Gr} 1{ }^{+}$cells of total spleen cells. ${ }^{*} P<0.05$. (C) Accumulation of CD11b+ and $\mathrm{Gr} 1{ }^{+}$cells in the spleen of tumor-bearing mice, determined by immunofluorescence staining (see Methods). Dotted outlines denote germinal centers. Images are representative of at least 3 mice. Original magnification, $\times 100$ (CD11b); $\times 200$ (Gr1). Scale bars: $300 \mu \mathrm{m}$. (D) Total cell lysates were prepared from isolated Tnfr1 ${ }^{-/-}$and Tnfr2 $2^{-/-}$CD11b+Gr1+ cells after stimulation with $20 \mathrm{ng} / \mathrm{ml}$ TNF for the indicated times. Levels of TRAF2, $\mathrm{p}-\mathrm{NF}-\mathrm{kB} \mathrm{p} 65, \mathrm{p}-\mathrm{I} \mathrm{KB} \alpha$, and $\mathrm{p}-\mathrm{IKK} \alpha / \beta$, c-FLIP, and cleaved caspase-8 were determined by Western blot. See Figure $5 \mathrm{C}$ for expression levels of respective molecules in $\mathrm{Tnfr}^{+/+}$mice (controls). $\beta$-actin was used as an internal control. Representative images are shown for 3 independent experiments.

MDSC accumulation is also influenced by many other factors, such as cyclooxygenase2, prostaglandins, SCF, M-CSF, GM-CSF, IL-1 $\beta$, IL-6, S100A8/9, and VEGF (31-35). These factors are critical not only in the expansion of MDSCs, but also, more importantly, in their functional activation. Both processes are mainly regulated by the same set of transcription factors, i.e., STAT3, STAT1, STAT6, and NF-кB $(36,37)$. Blockade of factors such as S100A8/9 impairs MDSC accumulation (34). Besides, recent researches report that activation of the Fas/FasL pathway (38) or blockade of the IL-4R $\alpha /$ STAT6 pathway (39) also promote MDSC apoptosis. It is not presently clear whether these factors function separately or synergistically or interact with TNF in MDSC accumulation. In-depth studies may further understanding of the general process of MDSC induction and accumulation in peripheral tissues. Moreover, since our experiments did not formally exclude that TNF signaling might also influence MDSC differentiation, other potential causes of peripheral MDSC accumulation remain to be studied.

Signaling of TNFR-2, but not TNFR-1, was crucial for MDSC accumulation. Different from TNFR-1, TNFR-2 lacks an intracellular death domain and predominantly confers signals for activation, proliferation, and survival of immune-regulatory cells. TNFR-2 deficiency on MDSCs eliminated their tumor-promot- 
A

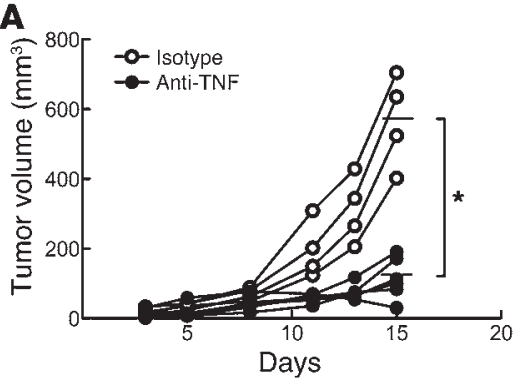

c

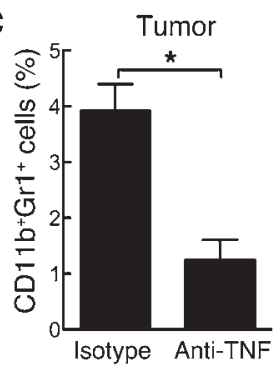

B

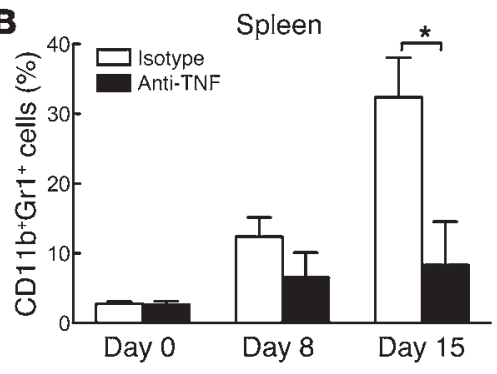

D

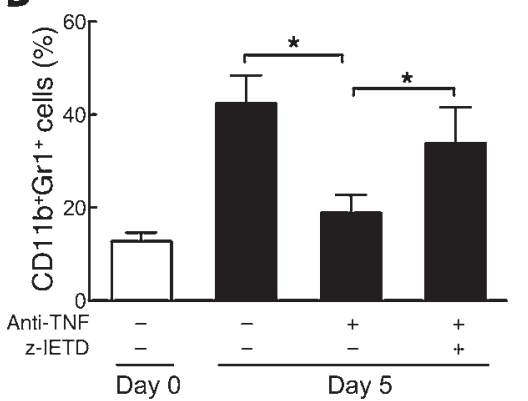

\section{Figure 7}

Neutralization of endogenous TNF impairs transplanted tumor growth and peripheral accumulation of CD11b+Gr1+ cells. (A) $\mathrm{Tnfr}^{+/+}$mice were intraperitoneally injected with the TNF-neutralizing mAb V1q $(n=6)$ or isotype control mAb $(n=4) 2$ days prior to subcutaneous injection of $1 \times 10^{6} \mathrm{FB} 61$ cells. $\mathrm{mAb}$ injection was repeated 3 and 8 days after tumor cell inoculation. Each line represents the growth curve of a tumor in a single mouse; bars denote mean tumor size of each group at day $15 .{ }^{*} P<0.05$. (B and $\mathbf{C}$ ) Spleen or tumor cells were isolated after tumor cell inoculation and stained for flow cytometry. Shown are percent $\mathrm{CD} 11 \mathrm{~b}^{+} \mathrm{Gr} 1^{+}$cells in (B) total spleen cells and $(\mathbf{C})$ total tumor cells at days $8-10$ (mean \pm SEM). $n=3-5$ per group. ${ }^{*} P<0.05$. (D) Bone marrow cells isolated from $\mathrm{Tnfr}^{+/+}$mice were induced for MDSC generation in vitro (see Methods). V1q, z-IETD, or DMSO (as control) was added to the culture after 6 hours. Cells were collected 5 days later and stained for CD11b and Gr1. Data (mean \pm SEM) represent percent $\mathrm{CD} 11 \mathrm{~b}+\mathrm{Gr} 1{ }^{+}$cells within total living cells in the culture. ${ }^{*} P<0.05$. ing effects (Figure 6A) and peripheral accumulation (Figure 6, $B$ and $C$ ), whereas their immunosuppressive capacity was maintained (Supplemental Figure 7). In the absence of TNFRs, MDSCs exhibited decreased c-FLIP and increased cleaved caspase- 8 under TNF stimulation (Figure 5C). Emphasizing the role of TNFdependent TNFR-2 signaling, TNFR-2 expression was sufficient to restore this variation, whereas expression of TNFR-1 failed to do so (Figure 6D). Recent studies demonstrated that TNFR-2 is predominantly expressed on Tregs as a surface marker involved in their expansion and activation $(40,41)$. Interestingly, although MDSCs are important inducers of Tregs (42), the proportion of $\mathrm{CD}^{+}{ }^{+} \mathrm{Foxp}^{+}$cells in $\mathrm{Tnfr}^{-/-}$mouse spleens was not significantly decreased (Supplemental Figure 2A), which might be due to our observation of an early stage of tumor progression (days 8-10).

MDSC accumulation is induced not only by tumor growth, but also by many other kinds of chronic inflammation (28). We previously found that subcutaneously inoculated CFA can sufficiently induce a $\mathrm{CD} 11 \mathrm{~b}^{+} \mathrm{Gr} 1^{+}$cell population. These cells, similar to those induced in tumor-bearing hosts, produce plenty of NO and strongly inhibit T cell-mediated rejection of tumor transplants (28). CFA-induced splenic MDSC accumulation in $\mathrm{Tnfr}^{-1-}$ mice was inferior to that in $\mathrm{Tnfr}^{+/+}$mice. Caspase- 8 activity in these MDSCs was also enhanced (data not shown). These observations suggest that the requirement of host TNFR expression on MDSC accumulation is not tumor specific, but more general for inflammation.

The major source of endogenous TNF here for MDSC accumulation could be the MDSCs themselves. These cells produce a large amount of TNF, regardless of their TNFR expression. In contrast, like most of the mouse tumor cell lines available, the tumor cells used in this study did not secrete detectable TNF (Supplemental Figure 8). Therefore, it is highly possible that a TNF/TNFR-2 autocrine loop functions during survival as well as accumulation of MDSCs. Other acknowledged sources of TNF include neutrophils, B cells, and Th1 and Th17 lymphocytes $(43,44)$; at present, the probability of a paracrine pathway cannot be formally excluded.
In tumor-bearing mice, MDSCs accumulate in central (bone marrow) and peripheral (spleen, blood, draining lymph nodes) organs as well as in tumor sites. Our results showed decreased proportions of MDSCs in spleen, peripheral blood, and tumor sites of $\mathrm{Tnfr}^{-1-}$ mice (Figure 2, A-E). In bone marrow of tumorbearing or CFA-injected Tnfr-/- mice, the proportion of MDSCs was comparable to that in corresponding $\mathrm{Tnfr}^{+/+}$mice (data not shown). These findings underline the crucial role of TNFR signaling in peripheral MDSC accumulation, which mainly affects local but not systematic inflammatory responses, despite the diversity of MDSC populations distributing differently in every organ and the predominance of myeloid precursors in the bone marrow (45).

Targeting TNF is becoming a treatment option in both cancer (46) and immune-mediated chronic inflammatory diseases, such as rheumatoid arthritis and ankylosing spondylitis (47). In mice, TNF blockade inhibits tumor progression and/or metastasis in several transplanted and carcinogen-induced tumor models $(12,18)$. In humans, TNF blockade has shown some evidence of anticancer activity in phase I and phase II clinical trials (46). However, the anti-TNF therapy is still in the initial stages $(43,48)$. In humans, MDSCs are defined as cells that express the common myeloid marker CD33, but lack the markers of mature myeloid and lymphoid cells (37). We have examined the dynamic changes of MDSCs in human ankylosing spondylitis patients before and after treatment with adalimumab, a clinically used anti-TNF reagent. The proportion of $\mathrm{CD} 14^{-} \mathrm{CD} 11 \mathrm{~b}^{+} \mathrm{CD} 33^{+}$cells decreased 12 weeks after adalimumab treatment and remained low until the end of the treatment (our unpublished observations). These clinical observations on TNFR-related effects on myeloid cells are consistent with our present findings in the mouse models (Figure 7). Moreover, in RA patients, the anti-TNF reagents etanercept and infliximab induce apoptosis in monocytes and macrophages in the synovial fluid and in the peripheral blood (49).

Collectively, this study shows that, in the transplanted tumor model, endogenous chronic TNF signaling promotes tumor growth by maintaining MDSC survival. Our results suggest a pos- 
sible mechanism of anti-TNF reagent in treating such inflammatory diseases and also indicate a possible therapeutic benefit of anti-TNF reagent in clinical trials against cancers.

\section{Methods}

Mice. Tnfr1 $1^{-/-}$, Tnfr2 $2^{-/}$, Tnfr ${ }^{--}$, and $\mathrm{Tnfr}^{+/+}$mice on BALB/c background were generated as described previously (13). The eGFP-transgenic mice, Tnfr ${ }^{-1}$ and their $T n f^{+/+}$wild-type controls, on a C57BL/ 6 background were obtained from the Jackson Laboratory. All mice were bred in the specific pathogenfree barrier facility of Institute of Biophysics, Chinese Academy of Sciences. In all experiments described here, female mice aged 6-8 weeks were used.

Cell lines. J558L, a plasmacytoma cell line of BALB/c origin (50), expressed both TNFR-1 and TNFR-2 on the cell surface (data not shown). J558L cells were passed in nude mice for 3 generations before inoculation into $\mathrm{Tnfr}^{+/+}$ and $\mathrm{Tnfr}^{-/-}$mice. To generate the $\mathrm{Tnfr} \mathrm{1}^{-/-}$and $\mathrm{Tnfr}^{-/-}$fibrosarcoma cell lines, MCA (Sigma-Aldrich) emulsified in sesame oil was intramuscularly injected into $\operatorname{Tnfr} 1^{-/-}$or Tnfr ${ }^{-/}$mice (51). The MCA-induced tumors were excised at a size of $1 \mathrm{~cm}$ in diameter and cut into small fragments of about $3 \times 3 \times 3 \mathrm{~mm}$. Tumor fragments were subsequently grafted twice onto nude mice, twice onto Tnfr1 $1^{-/-}$or Tnfr- mice, and twice onto $\mathrm{Tnfr}^{+/+} \mathrm{BALB} / \mathrm{c}$ mice. Tumor nodules were then isolated, minced, and digested to obtain single-cell suspension using trypsin/EDTA solution. After at least 5 passages in vitro, the Tnfr1 $1^{-/-}$cell line FB61 (52) and the Tnfr $/-$cell line FD99 were randomly chose for further experiments. MCA205 is a MCA-induced fibrosarcoma cell line of C57BL/6 origin (53). All tumor cells were cultured in RPMI 1640 medium supplemented with $10 \%$ fetal calf serum, $100 \mathrm{U} / \mathrm{ml}$ penicillin, and $100 \mu \mathrm{g} / \mathrm{ml}$ streptomycin (all Gibco).

In vivo studies. Exponentially growing tumor cells were harvested, washed, and injected subcutaneously into the abdomen region of mice. Tumor growth was monitored every 2-5 days, and tumor volume was calculated as $(l \times w \times w) / 2$. To neutralize endogenous TNF, each mouse was intraperitoneally injected with ascites containing $0.5 \mathrm{mg} \mathrm{mAb}$ V1q every 5 days (starting at 2 days before tumor inoculation, up to 3 injections).

Isolation and adoptive transfer of MDSCs. CD $11 \mathrm{~b}^{+} \mathrm{Gr} 1^{+}$cells were collected as described previously $(28,29)$. Briefly, mice were subcutaneously injected with $1 \times 10^{6} \mathrm{FB} 61$ tumor cells. When tumors were at least $1 \mathrm{~cm}$ in diameter at day $8-10$, single-cell suspensions from the spleens of tumor-bearing mice were fractionated by Percoll (Amersham Biosciences) density gradient centrifugation. $\mathrm{CD} 11 \mathrm{~b}^{+} \mathrm{Gr} 1^{+}$cells were subsequently isolated using mouse MDSC isolation kits (provided by Miltenyi Biotec) according to the manufacturer's protocol. The purity of $\mathrm{CD} 11 \mathrm{~b}^{+} \mathrm{Gr} 1^{+}$cells was consistently greater than $92 \%$ in all samples, assessed by flow cytometry (data not shown). For adoptive transfer, $5 \times 10^{6}$ isolated $\mathrm{CD} 11 \mathrm{~b}^{+} \mathrm{Gr} 1^{+}$cells were injected through tail vein. To study the fate of adoptively transferred MDSCs, eGFP-transgenic mice were subcutaneously injected with $1 \times 10^{6}$ MCA205 tumor cells. When tumors were at least $1 \mathrm{~cm}$ in diameter at day $8-10, \mathrm{CD} 11 \mathrm{~b}^{+} \mathrm{Gr} 1^{+}$cells were isolated as described above, and $5 \times 10^{6}$ cells were injected through tail vein of $\mathrm{Tnfr}^{+/+}$syngeneic recipient mice on C57BL/6 background.

Flow cytometry analysis. Single-cell suspensions prepared directly from peripheral blood, spleen, and tumor tissue were stained with the following directly labeled mouse-specific mAbs: FITC-labeled CD11b, Gr1, Foxp3, and annexin $\mathrm{V}$ (BD Biosciences - Pharmingen); PE-labeled Gr1, CD11b, CD80, CD86, CD95, CD95L, B7-H1, IL-4R, H2-K ${ }^{\mathrm{d}}$, I-A ${ }^{\mathrm{d}}$, TNFR-1, and TNFR-2 (BD Biosciences - Pharmingen); APC-labeled CD4, B220, and CD11c (BD Biosciences - Pharmingen); PerCP-labeled CD8 and CD11b (BD Biosciences -Pharmingen); FITC-labeled CD4 (Sungene Biotech); APC-labeled IL-17A (eBioscience); and PE-labeled anti-BrdU (BioLegend). To determine the proportion of IFN- $\gamma$-producing T cells, $1 \times 10^{6}$ spleen cells were stimulated with PMA (50 ng/ml; Sigma-Aldrich) and ionomycin $(500 \mathrm{ng} / \mathrm{ml}$; Sigma-Aldrich) for 0.5 hours before administration of brefeldin A (10 $\mu \mathrm{g} / \mathrm{ml}$; Sigma-Aldrich) for an additional 4 hours. Cells were stained for CD4 and CD8, treated with Fixation and Permeabilization Solution (BD Biosciences), and then stained with PE-labeled anti-mouse IFN- $\gamma$ antibody (BD Biosciences). Data were acquired with a FACS Calibur flow cytometer (BD Biosciences) and analyzed using Cell Quest-Pro (BD Biosciences) or FlowJo (FlowJo) software. To determine IL-10 or TNF production, $2 \times 10^{5}$ purified $\mathrm{CD} 11 \mathrm{~b}^{+} \mathrm{Gr} 1^{+}$cells or $2 \times 10^{4} \mathrm{~J} 558 \mathrm{~L}$, FB61, or FD99 tumor cells were cultured in 96-well plates with $200 \mu$ l RPMI 1640 medium supplemented with $10 \%$ fetal calf serum (Gibco), then stimulated with LPS $(1 \mu \mathrm{g} / \mathrm{ml}$; Sigma-Aldrich) and IFN- $\gamma(50 \mathrm{ng} / \mathrm{ml}$; PeproTech) as described previously (54). Supernatants were collected after 16 hours. The content of IL-10 or TNF was measured with the mouse inflammation cytometric bead array kit (CBA; BD Biosciences).

Induction of MDSCs in vitro. Induction of $\mathrm{CD} 11 \mathrm{~b}^{+} \mathrm{Gr} 1^{+}$cells from bone marrow progenitors was done as described previously $(55,56)$. In brief, bone marrow cells were obtained from the femurs and tibias. $1 \times 10^{6}$ bone marrow cells were cultured in 24-well plates in media conditioned by EL4 tumor cells, supplemented with $10 \%$ fetal calf serum (Gibco), $20 \mathrm{ng} / \mathrm{ml}$ GM-CSF (PeproTech), and $10 \mathrm{ng} / \mathrm{ml} \mathrm{IL-4} \mathrm{(PeproTech).} \mathrm{Cells} \mathrm{were} \mathrm{collected}$ 5 days later, and the proportion of $\mathrm{CD} 11 \mathrm{~b}^{+} \mathrm{Gr} 1^{+}$cells was analyzed by flow cytometry. Pan-caspase inhibitor z-VAD and caspase-8-specific inhibitor z-IETD (20 $\mu \mathrm{M}$ each; Bachem) were dissolved in DMSO. To block endogenous TNF, $5 \mu \mathrm{g} / \mathrm{ml} \mathrm{V1q} \mathrm{mAb}$ was added to the culture.

$B r d U$ incorporation. Each mouse was intraperitoneally injected with $100 \mu \mathrm{l} \mathrm{BrdU}(10 \mathrm{mg} / \mathrm{ml}$; Sigma-Aldrich) 3, 5, and 8 days after the inoculation of FB61 cells. 24 hours after each BrdU injection, the proportion of $\mathrm{CD} 11 \mathrm{~b}^{+} \mathrm{Gr} 1^{+}$cells with BrdU incorporation in total $\mathrm{CD} 11 \mathrm{~b}^{+} \mathrm{Gr} 1^{+}$cells in bone marrow was determined by flow cytometry analysis.

Immunofluorescent staining. Groups of mice were subcutaneously injected with $1 \times 10^{6} \mathrm{FB} 61$ cells; $8-10$ days later, mice with a tumor about $200 \mathrm{~mm}^{3}$ in size were sacrificed. Tumors and spleens were fixed and prepared for cryostat sections as previously described (29). Tissue sections $(7 \mu \mathrm{m}$ for tumors; $5 \mu \mathrm{m}$ for spleens) were incubated with rat anti-mouse mAbs specific to CD4, CD8, CD11b, CD31, or Gr1 (all from BD Biosciences) and anti-GFP rabbit serum (Life Technologies). For detection of primary antibody binding, sections were incubated with Alexa Fluor 555 goat anti-rat or Alexa Fluor 488 goat anti-rabbit IgG (Life Technologies). Primary antibodies were omitted in negative controls. Nuclei were counterstained by DAPI (Sigma-Aldrich), and slides were mounted for fluorescence observation on an Olympus FV1000 confocal microscope. Tissue sections from at least 3 mice per group were evaluated.

$T$ cell proliferation assay. The $\mathrm{T}$ cell proliferation assay was performed as previously described $(28,57)$, with slight modifications. To determine the immune-suppressive function of MDSCs, splenocytes of tumor-free $\mathrm{Tnfr}^{+/+}$ mice were labeled with $2.5 \mathrm{mM}$ CFSE (Molecular Probes) for 10 minutes at $37^{\circ} \mathrm{C}$ and distributed in 96-well round-bottomed plates, with $3 \times 10^{5}$ cells and $100 \mu \mathrm{l}$ RMPI 1640 medium per well. These cells were cultured

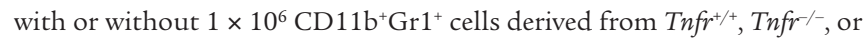
Tnfr2-- FB61 tumor-bearing mice or tumor-free controls and stimulated with $2.5 \mathrm{mg} / \mathrm{ml}$ concanavalin A (Sigma-Aldrich) for 72 hours. For stimulating specific $\mathrm{T}$ cell proliferation, spleen cells from $\mathrm{Tnfr}^{+/+} \rightarrow \mathrm{Tnfr}^{-/-}$or $\mathrm{Tnfr}^{-1-} \rightarrow \mathrm{Tnfr}^{-1-}$ mice were CFSE labeled, and $3 \times 10^{5}$ cells were plated in $100 \mu 1$ medium per well as described above. FB61 cell lysate (made from 3 freeze-thaw cycles) was added at a 1:40 FB61/splenocyte ratio by cell counts. After 72 hours, cells were collected and stained. The dilution of CFSE in $\mathrm{CD}^{+}$and $\mathrm{CD}^{+} \mathrm{T}$ cells was determined by flow cytometry analysis.

Real time RT-PCR. Total RNA was extracted from $1 \times 10^{7}$ isolated $\mathrm{CD} 11 \mathrm{~b}^{+} \mathrm{Gr} 1^{+}$cells with TRIzOL (Invitrogen) and quantified on a ND-1000 spectrophotometer (NanoDrop Technologies). The cDNA was synthesized with $2 \mu \mathrm{g}$ RNA, $9 \mathrm{nt}$ random primer (TaKaRa), and M-MLV reverse 
transcriptase (Promega). The amount of Bcl- $\mathrm{x}_{\mathrm{L}}$ or $\mathrm{c}-\mathrm{FLIP}$ mRNA was determined using iQTM SYBR Green Supermix on MyiQTM system (Bio-Rad Laboratories). $\beta$-actin mRNA was used as internal control. Specific primers were as follows: Bcl- $\mathrm{x}_{\mathrm{L}}, 5^{\prime}$-ACAGAGCAGACCCAGTAAGT-3' and 5'-ACCGCAGTTCAAACTCAT-3'; c-FLIP, $5^{\prime}$-TTGATTGTATTGGCAACG-3' and $5^{\prime}$-AACTGGCTACCTAACGACT-3'; $\beta$-actin, $5^{\prime}$-GAAGTGTGACGTTGACATCCGTA-3' and 5'-CTCAGGAGGAGCAATGATCTTGA-3'.

Western blot. Cells were lysed by RIPA solution (50 mM Tris- $\mathrm{HCl}$ [ $\mathrm{pH} 7.5]$, $150 \mathrm{mM} \mathrm{NaCl}, 1.0 \%$ Nonidet P-40, $0.5 \%$ [w/v] sodium deoxycholate, $0.1 \%$ [w/v] SDS, $1 \mathrm{mM}$ EDTA) supplemented with $100 \mu \mathrm{M}$ phenylmethanesulfonyl fluoride, $25 \mu \mathrm{g} / \mathrm{ml}$ aprotinin, $1 \mathrm{mmol} / 1$ sodium orthovanadate, and $50 \mathrm{mmol} / 1 \mathrm{NaF}$. Aliquots of cell extracts were resolved on $10 \%$ SDSPAGE gel, then transferred to nitrocellulose membrane (GE Healthcare) on a semidry transfer apparatus (Bio-Rad Laboratories). Primary antibodies used were as follows: Bcl- $\mathrm{x}_{\mathrm{L}}$ (H-5, 1:1,000; Santa Cruz), caspase-8 (D-8, 1:1,000; Santa Cruz), c-FLIP (catalog no. 3210, 1:1,000; Cell Signaling Technology), p-NF-кB p65 (Ser536) (clone 93H1, 1:1,000; Cell Signaling Technology), TRAF2 (Cys192) (1:1,000; Cell Signaling Technology), p-IKK $\alpha / \beta$ (Ser176/180) (clone 16A6, 1:1,000; Cell Signaling Technology), $\mathrm{p}-\mathrm{I \kappa B} \alpha$ (Ser32) (clone 14D4, 1:1,000; Cell Signaling Technology), and $\beta$-actin (1:8,000; Sigma-Aldrich). HRP-conjugated goat anti-mouse or goat anti-rabbit IgG (Thermo) were used as secondary antibodies. After washing with PBST, the membrane was incubated with chemiluminescent substrate (Thermo) for 5 minutes. Specific bands were visualized by exposing the membrane to X-ray film (Kodak) in a dark room. To determine the extent of molecule involvement in the TNF signaling pathway, isolated $\mathrm{CD} 11 \mathrm{~b}^{+} \mathrm{Gr} 1^{+}$cells were stimulated with murine recombinant TNF (20 ng/ $\mathrm{ml}$; PeproTech) for different time periods before collection.

Caspase-8 activity. $\mathrm{CD} 11 \mathrm{~b}^{+} \mathrm{Gr} 1^{+}$cells were freshly isolated from $\mathrm{Tnfr} \mathrm{r}^{+/+}$and $\mathrm{Tnfr}^{-1}$ FB61 tumor-bearing mice. The activity of caspase- 8 was detected by a caspase-8 Colorimetric Assay Kit (catalog no. K113; BioVision) according to the manufacturer's instructions. Briefly, $1 \times 10^{6}$ cells were lysed with $50 \mu \mathrm{l}$ chilled cell lysis buffer. The lysate was supplemented with $200 \mu \mathrm{M}$ IETD-pNA substrate and incubated at $37^{\circ} \mathrm{C}$ for $1-2$ hours. Absorbance at $400 \mathrm{~nm}$ was read in a microplate reader (Bio-Rad Laboratories).

Arginase activity. Arginase activity was determined by measuring the amount of urea generated from the hydrolysis of L-arginine, as described previously (29). Briefly, $1 \times 10^{6}$ isolated $\mathrm{CD} 11 \mathrm{~b}^{+} \mathrm{Gr} 1^{+}$cells were solubilized with $100 \mu$ lysis solution $\left(0.1 \%\right.$ Triton X-100, $10 \mathrm{mM} \mathrm{MnCl}_{2}, 25 \mathrm{mM}$ Tris$\mathrm{HCl}$ ). Lysate was activated at $56^{\circ} \mathrm{C}$ for 10 minutes, supplemented with $200 \mu \mathrm{l} \mathrm{0.5} \mathrm{M} \mathrm{L-arginine} \mathrm{(} \mathrm{pH} 9.7$ ), and then incubated at $37^{\circ} \mathrm{C}$ for $60 \mathrm{~min}$ utes. The reaction was stopped by $800 \mu \mathrm{l} \mathrm{H}_{2} \mathrm{SO}_{4} / \mathrm{H}_{3} \mathrm{PO}_{4} / \mathrm{H}_{2} \mathrm{O}(1: 3: 7 \mathrm{v} / \mathrm{v} / \mathrm{v})$.
Subsequently, $40 \mu \mathrm{l} \alpha$-isonitrosopropiophenone (dissolved in ethanol; Sigma-Aldrich) was added, followed by another heating at $100^{\circ} \mathrm{C}$ for 30 minutes. The concentration of urea was measured by $540 \mathrm{~nm}$ absorbance. $1 \mathrm{U}$ enzyme activity was defined as the amount of enzyme that catalyzes the formation of $1 \mu \mathrm{mol}$ of urea per minute. Data are presented as mean $\pm \mathrm{SEM}$ of triplicate wells.

iNOS activity. The activity of iNOS was measured by Nitric Oxide Synthase Assay Kit (Beyotime) according to the manufacturer's instructions. Briefly, $2 \times 10^{5}$ isolated $\mathrm{CD} 11 \mathrm{~b}^{+} \mathrm{Gr} 1^{+}$cells were cultured in 96-well plates, then stimulated with LPS $(1 \mu \mathrm{g} / \mathrm{ml}$; Sigma-Aldrich $)$ and IFN- $\gamma(50 \mathrm{ng} / \mathrm{ml}$; PeproTech) with or without the iNOS-specific inhibitor S-methylisothiourea sulfate (SMT; $1 \mathrm{mM}$; Sigma-Aldrich) for 8 hours at $37^{\circ} \mathrm{C}$. Culture supernatant was removed, and $100 \mu \mathrm{l}$ NOS assay buffer was added to each well, followed by $100 \mu \mathrm{l}$ NOS assay reaction solution (50\% NOS assay buffer, 39.8\% MilliQ water, 5\% L-arginine solution, 5\% 0.1 mM NADPH, $0.2 \%$ fluorescent probes diaminofluorescein-diacetate), and incubated for 2 hours at $37^{\circ} \mathrm{C}$. Relative fluorescence units (RFUs) were measured with a fluorescence plate reader (BioTek) at $485 \mathrm{~nm}$ excitation and $535 \mathrm{~nm}$ emission. iNOS activity was assessed as the difference between RFUs with stimulation alone and RFUs with stimulation plus SMT. Data were presented as mean \pm SEM of triplicate wells.

Statistics. Differences between 2 groups were analyzed by 2 -tailed Student's $t$ test. A $P$ value less than 0.05 was considered significant.

Study approval. All protocols concerning animal use were approved by the Institutional Animal Care and Use Committee of Institute of Biophysics, Chinese Academy of Sciences.

\section{Acknowledgments}

The authors thank Miltenyi Biotec for providing mouse MDSC isolation kits. This work was supported by the Ministry of Science and Technology of China (2012CB917103 and 2012CB934003), the National Natural Science Foundation of China (81030049, 31071261, and 81001328), and the Ministry of Education, Culture, Sports, Science and Technology (MEXT) of Japan.

Received for publication April 3, 2012, and accepted in revised form August 30, 2012.

Address correspondence to: Zhihai Qin, Institute of Biophysics, Chinese Academy of Sciences, 15 Datun Road, Beijing 100101, China. Phone: 86.10.64888435; Fax: 86.10.64888570; E-mail: zhihai@ibp.ac.cn.
1. Mantovani A, Allavena P, Sica A, Balkwill F. Cancer-related inflammation. Nature. 2008; 454(7203):436-444.

2. Hanahan D, Weinberg RA. Hallmarks of cancer: the next generation. Cell. 2011;144(5):646-674.

3. Pekarek LA, Starr BA, Toledano AY, Schreiber H. Inhibition of tumor growth by elimination of granulocytes. J Exp Med. 1995;181(1):435-440.

4. Gabrilovich DI, Nagaraj S. Myeloid-derived suppressor cells as regulators of the immune system. Nat Rev Immunol. 2009;9(3):162-174.

5. Serafini P, et al. Derangement of immune responses by myeloid suppressor cells. Cancer Immunol Immunother. 2004;53(2):64-72.

6. Yang L, et al. Expansion of myeloid immune suppressor $\mathrm{Gr}+\mathrm{CD} 11 \mathrm{~b}+$ cells in tumor-bearing host directly promotes tumor angiogenesis. Cancer Cell. 2004;6(4):409-421.

7. Kusmartsev S, Nagaraj S, Gabrilovich DI. Tumorassociated CD8+ T cell tolerance induced by bone marrow-derived immature myeloid cells. J Immunol. 2005;175(7):4583-4592.
8. Shojaei F, et al. Tumor refractoriness to anti-VEGF treatment is mediated by CD $11 \mathrm{~b}+\mathrm{Gr} 1+$ myeloid cells. Nat Biotechnol. 2007;25(8):911-920.

9. Balkwill F. TNF-alpha in promotion and progression of cancer. Cancer Metastasis Rev. 2006;25(3):409-416.

10. Oliff A, et al. Tumors secreting human TNF/cachectin induce cachexia in mice. Cell. 1987;50(4):555-563.

11. Blankenstein $\mathrm{T}$, et al. Tumor suppression after tumor cell-targeted tumor necrosis factor alpha gene transfer. J Exp Med. 1991;173(5):1047-1052.

12. Qin Z, Kruger-Krasagakes S, Kunzendorf U, Hock H, Diamantstein T, Blankenstein T. Expression of tumor necrosis factor by different tumor cell lines results either in tumor suppression or augmented metastasis. J Exp Med. 1993;178(1):355-360.

13. Zhao X, Mohaupt M, Jiang J, Liu S, Li B, Qin Z. Tumor necrosis factor receptor 2-mediated tumor suppression is nitric oxide dependent and involves angiostasis. Cancer Res. 2007;67(9):4443-4450.

14. Swann JB, et al. Demonstration of inflammationinduced cancer and cancer immunoediting during primary tumorigenesis. Proc Natl Acad Sci U S A.
2008;105(2):652-656.

15. Calzascia T, et al. TNF-alpha is critical for antitumor but not antiviral $\mathrm{T}$ cell immunity in mice. J Clin Invest. 2007;117(12):3833-3845.

16. Kulbe H, et al. The inflammatory cytokine tumor necrosis factor-alpha generates an autocrine tumor-promoting network in epithelial ovarian cancer cells. Cancer Res. 2007;67(2):585-592.

17. Moore RJ, et al. Mice deficient in tumor necrosis factor-alpha are resistant to skin carcinogenesis. Nat Med. 1999;5(7):828-831.

18. Scott KA, et al. An anti-tumor necrosis factor-alpha antibody inhibits the development of experimental skin tumors. Mol Cancer Ther. 2003;2(5):445-451.

19. Arnott CH, Scott KA, Moore RJ, Robinson SC, Thompson RG, Balkwill FR. Expression of both TNF-alpha receptor subtypes is essential for optimal skin tumour development. Oncogene. 2004; 23(10):1902-1910.

20. Kitakata H, Nemoto-Sasaki Y, Takahashi Y, Kondo T, Mai M, Mukaida N. Essential roles of tumor necrosis factor receptor p55 in liver metastasis of 
intrasplenic administration of colon 26 cells. Cancer Res. 2002;62(22):6682-6687.

21. Fong L, Engleman EG. Dendritic cells in cancer immunotheratpy. Annu Rev Immunol. 2000; 18:245-273.

22. Geissmann F, Manz MG, Jung S, Sieweke MH, Merad M, Ley K. Development of monocytes, macrophages, and dendritic cells. Science. 2010;327(5966):656-661.

23. Hehlgans T, Pfeffer K. The intriguing biology of the tumour necrosis factor/tumour necrosis factor receptor superfamily: players, rules and the games. Immunology. 2005;115(1):1-20.

24. Kelliher MA, Grimm S, Ishida Y, Kuo F, Stanger BZ, Leder P. The death domain kinase RIP mediates the TNF-induced NF-kappaB signal. Immunity. 1998;8(3):297-303.

25. Yeh WC, et al. Early lethality, functional NF-kap$\mathrm{paB}$ activation, and increased sensitivity to TNFinduced cell death in TRAF2-deficient mice. Immunity. 1997;7(5):715-725.

26. Vallabhapurapu S, Karin M. Regulation and function of NF-kappaB transcription factors in the immune system. Annu Rev Immunol. 2009;27:693-733.

27. Wu TH, et al. Long-term suppression of tumor growth by TNF requires a Stat 1 - and IFN regulatory factor 1-dependent IFN-gamma pathway but not IL-12 or IL-18. J Immunol. 2004;172(5):3243-3251.

28. Wang Z, Jiang J, Li Z, Zhang J, Wang H, Qin Z. A myeloid cell population induced by Freund adjuvant suppresses T-cell-mediated antitumor immunity. J Immunother. 2010;33(2):167-177.

29. Jiang J, et al. Early exposure of high-dose interleukin-4 to tumor stroma reverses myeloid cell-mediated T-cell suppression. Gene Ther. 2010;17(8):991-999.

30. Chen G, Goeddel DV. TNF-R1 signaling: a beautiful pathway. Science. 2002;296(5573):1634-1635.

31. Bunt SK, Sinha P, Clements VK, Leips J, OstrandRosenberg S. Inflammation induces myeloidderived suppressor cells that facilitate tumor progression. J Immunol. 2006;176(1):284-290.

32. Bunt SK, Yang L, Sinha P, Clements VK, Leips J, Ostrand-Rosenberg S. Reduced inflammation in the tumor microenvironment delays the accumulation of myeloid-derived suppressor cells and limits tumor progression. Cancer Res. 2007;67(20):10019-10026.

33. Sinha P, Clements VK, Fulton AM, Ostrand-Rosenberg S. Prostaglandin E2 promotes tumor progres- sion by inducing myeloid-derived suppressor cells. Cancer Res. 2007;67(9):4507-4513.

34. Sinha P, Okoro C, Foell D, Freeze HH, Ostrand-Rosenberg S, Srikrishna G. Proinflammatory S100 proteins regulate the accumulation of myeloid-derived suppressor cells. J Immunol. 2008;181(7):4666-4675.

35. Song X, et al. CD11b+/Gr-1+ immature myeloid cells mediate suppression of $\mathrm{T}$ cells in mice bearing tumors of IL-1beta-secreting cells. J Immunol. 2005;175(12):8200-8208.

36. Sonda N, Chioda M, Zilio S, Simonato F, Bronte $\mathrm{V}$. Transcription factors in myeloid-derived suppressor cell recruitment and function. Curr Opin Immunol. 2011;23(2):279-285.

37. Condamine T, Gabrilovich DI. Molecular mechanisms regulating myeloid-derived suppressor cell differentiation and function. Trends Immunol. 2011;32(1):19-25.

38. Sinha P, Chornoguz O, Clements VK, Artemenko KA, Zubarev RA, Ostrand-Rosenberg S. Myeloidderived suppressor cells express the death receptor Fas and apoptose in response to T cell-expressed FasL. Blood. 2011;117(20):5381-5390.

39. Roth F, De La Fuente AC, Vella JL, Zoso A, Inverard L, Serafini P. Aptamer-mediated blockade of IL4Ralpha triggers apoptosis of MDSCs and limits tumor progression. Cancer Res. 2012;72(6):1373-1383.

40. Chen X, Oppenheim JJ. The phenotypic and functional consequences of tumour necrosis factor receptor type 2 expression on CD4(+) FoxP3(+) regulatory T cells. Immunology. 2011;133(4):426-433.

41. Chen X, Baumel M, Mannel DN, Howard OM, Oppenheim JJ. Interaction of TNF with TNF receptor type 2 promotes expansion and function of mouse CD4+CD25+ T regulatory cells. J Immunol. 2007;179(1):154-161

42. Serafini P, Mgebroff S, Noonan K, Borrello I. Myeloid-derived suppressor cells promote crosstolerance in B-cell lymphoma by expanding regulatory T cells. Cancer Res. 2008;68(13):5439-5449.

43. Balkwill F. Tumour necrosis factor and cancer. Nat Rev Cancer. 2009;9(5):361-371.

44. Grivennikov SI, et al. Distinct and nonredundant in vivo functions of TNF produced by $t$ cells and macrophages/neutrophils: protective and deleterious effects. Immunity. 2005;22(1):93-104.

45. Youn JI, Gabrilovich DI. The biology of myeloidderived suppressor cells: the blessing and the curse of morphological and functional heterogeneity. Eur J Immunol. 2010;40(11):2969-2975.

46. Harrison ML, et al. Tumor necrosis factor alpha as a new target for renal cell carcinoma: two sequential phase II trials of infliximab at standard and high dose. J Clin Oncol. 2007;25(29):4542-4549.

47. Rosenblum H, Amital H. Anti-TNF therapy: safety aspects of taking the risk. Autoimmun Rev. 2011; 10(9):563-568.

48. Palladino MA, Bahjat FR, Theodorakis EA, Moldawer LL. Anti-TNF-alpha therapies: the next generation. Nat Rev Drug Discov. 2003;2(9):736-746.

49. Catrina AI, et al. Evidence that anti-tumor necrosis factor therapy with both etanercept and infliximab induces apoptosis in macrophages, but not lymphocytes, in rheumatoid arthritis joints: extended report. Artbritis Rheum. 2005;52(1):61-72.

50. Oi VT, Morrison SL, Herzenberg LA, Berg P. Immunoglobulin gene expression in transformed lymphoid cells. Proc Natl Acad Sci U S A. 1983;80(3):825-829.

51. Qin Z, Kim HJ, Hemme J, Blankenstein T. Inhibition of methylcholanthrene-induced carcinogenesis by an interferon gamma receptor-dependent foreign body reaction. J Exp Med. 2002;195(11):1479-1490.

52. Li Z, et al. Endogenous interleukin-4 promotes tumor development by increasing tumor cell resistance to apoptosis. Cancer Res. 2008;68(21):8687-8694.

53. Shu SY, Rosenberg SA. Adoptive immunotherapy of newly induced murine sarcomas. Cancer Res. 1985;45(4):1657-1662.

54. Sinha P, Clements VK, Bunt SK, Albelda SM, Ostrand-Rosenberg S. Cross-talk between myeloidderived suppressor cells and macrophages subverts tumor immunity toward a type 2 response. J Immunol. 2007;179(2):977-983.

55. Cheng $P$, et al. Inhibition of dendritic cell differentiation and accumulation of myeloid-derived suppressor cells in cancer is regulated by S100A9 protein. J Exp Med. 2008;205(10):2235-2249.

56. Youn JI, Nagaraj S, Collazo M, Gabrilovich DI. Subsets of myeloid-derived suppressor cells in tumorbearing mice. J Immunol. 2008;181(8):5791-5802.

57. Qin Z, Blankenstein T. CD4+ T cell--mediated tumor rejection involves inhibition of angiogenesis that is dependent on IFN gamma receptor expression by nonhematopoietic cells. Immunity. 2000; 12(6):677-686. 